\title{
On "Whistle" Sound Objects in English Everyday Conversation
}

\section{Reber, Elisabeth}

2020-01-02

Reber , E \& Couper-Kuhlen , E 2020 , ' On "Whistle" Sound Objects in English Everyday Conversation ', Research on Language and Social Interaction , vol. 53 , no. 1 , pp. 164-187 . https://doi.org/10.1080/08351813.2020.1712966

http://hdl.handle.net/10138/333984

https://doi.org/10.1080/08351813.2020.1712966

acceptedVersion

Downloaded from Helda, University of Helsinki institutional repository.

This is an electronic reprint of the original article.

This reprint may differ from the original in pagination and typographic detail.

Please cite the original version. 


\section{On "whistle" sound objects in English everyday conversation}

Elisabeth Reber ${ }^{\mathrm{a} *}$ and Elizabeth Couper-Kuhlen ${ }^{\mathrm{b} * *}$

anstitute of New Philologies - Modern Languages, University of Würzburg, Würzburg, Germany; ${ }^{b}$ Department of Finnish, Finno-Ugrian and Scandinavian Studies, University of Helsinki, Helsinki, Finland

*Corresponding author: Elisabeth Reber, Institute of New Philologies - Modern

Languages, University of Würzburg, Am Hubland, 97074 Würzburg, Germany, elisabeth.reber@uni-wuerzburg.de

** Second author: Elizabeth Couper-Kuhlen, Department of Finnish, Finno-Ugrian and Scandinavian Studies, PB 24, FI-00014 University of Helsinki, Finland, elizabeth.couper-kuhlen@helsinki.fi

((8576 words)) 


\section{On "whistle" sound objects in English everyday conversation}

In this paper we study the forms and functions of whistling in social interaction (see also Reber, 2012; Reber \& Couper-Kuhlen, 2010). Our analysis identifies two basic forms of conversational whistling, 1) melodic whistling, when participants whistle the tune of, e.g., a familiar song, and 2) non-melodic whistling. The focus in this paper lies on non-melodic whistles, which come in two contours linked to specific actions: a) the tonal whistle deployed for summoning (e.g., a domestic animal but also human participants) and b) the gliding whistle used for affect-laden responses to informings that breach a norm, often ones containing a numerical reference. The pitch contour used on the latter type of whistle matches those found for more lexical sound objects, e.g., "oh", "ah", and "wow". The data base for the study comprises a wide range of audio and video recordings of mundane American and British English telephone and face-to-face conversations.

Keywords: melodic whistling; non-melodic whistling; sound objects; English

\section{Introduction}

Although whistles are not part of the English language, we argue in this paper that specific types of whistle are "sound objects" which English speakers deploy systematically for implementing both initiating and responsive actions in social interaction. The argument is based on our findings from a study of whistles in American and British English mundane conversation (see also Reber, 2012, for British English). The study aims to

(1) identify and describe "whistle" sound objects as used systematically in social interaction,

(2) work out why whistles are deployed where they are, and what practical socialinteractional problem they provide a solution for, and

(3) address the implications - and challenges - of treating non-lexical vocal tract sounds as part of the inventory of communicative resources for social 
interaction. To shed light on (3), we will compare the use of the lexical response token wow with a non-lexical responsive whistle in similar interactional environments and discuss whether a responsive whistle can, like wow, function as a turn-constructional unit (TCU).

\section{Literature review}

In terms of how whistling sounds are used across speech communities, there is a distinction to be made between "whistly fricatives" (e.g., /ș//zi/ of Southern Bantu), "whistled languages" (e.g., Silbo Gomero, a Spanish-based whistled language of the Canary Islands; Rialland, 2005; cf. also Meyer, 2008), and "recreational whistles" (e.g., in English, German; Shosted, 2006, p. 2; cf. also Busnel \& Classe, 1976; Laver, 1994; Shadle, 1997). Acccording to Shosted (2006, p. 2), the recreational whistle, which can be labial or palatal, can also have paralinguistic functions. There is no vibration of the vocal folds, and the fundamental frequency can range from $500 \mathrm{~Hz}$ to $4,000 \mathrm{~Hz}$ (Shadle, 1983, 1997, p. 61-62; Shosted, 2006). ${ }^{1}$

Whistling as an interactional resource has not received much attention in past research. As the use of the label "recreational" in the phonetic literature suggests, whistling is commonly associated with melodies and tunes, often involving a lighthearted pastime. In his paper on whistling, Schegloff (2005) is concerned with the whistling of a well-known tune in an American English context, which he compares to "the surfacing of a 'leak' from a stream of 'subconsciousness"” (Schegloff, 2005, p. 19) on the part of the whistler. By contrast, Stevanovic (2013) focuses on the whistling or

1. In the conversational data we have examined, the whistles used do not exceed $2500 \mathrm{~Hz}$ in fundamental frequency (see below). 
humming - which she treats as functionally equivalent - of an "unidentifiable" tune. Her analysis of English, Estonian, and Finnish data finds that humming is "not only a 'symptom' of nonparticipation, but it can also be used as a resource to establish nonparticipation and, thereby, to manage different kinds of interactional problems" (Stevanovic, 2013, p. 119). We will call this type of whistling, which involves melodies or tunes that may or may not be immediately recognizable to co-participants, melodic whistling (see Section 4).

On the other hand, our earlier work has shown that participants can also whistle specific contours to perform specific social actions, forms of whistling which we will call non-melodic whistling (see Section 5). Reber describes a whistling sound which comes in the form of a high-pitched, gliding (rise-)fall that fades out towards the end and exceeds the speaker's regular voice range markedly. She argues that this kind of whistle can serve as a news receipt in ways similar to lexical "sound objects", i.e., certain types of ahs and ohs, in that it is produced in the same sequential slot following informings. ${ }^{2}$ What is specific to the sound object "responsive whistle" is that participants often deploy it to take up informings which make reference to a numerical figure, displaying heightened appreciation but not ascribing specific affective valence to the new information (Reber, 2012, p. 236-241).

2. Sound objects are defined as "conversational objects with [phonetic substance but] minimal semantic content". The term sound object "aims to reflect the fact that these objects are spoken language resources for which the sound pattern and its context-specific use are distinctive for the meaning". Included are "so-called 'primary interjections', such as, e.g., $o h, a h$ and $o o h$, and non-lexical sounds such as clicks and whistling, which have been found to function similarly in talk-in-interaction" (Reber, 2012, p. 12; s. also Reber, 2009, Fn 5). 
While this earlier work was restricted to a very limited sample of British English telephone conversation, the present study revisits these findings with a broader and more varied data base, incorporating American English and videotaped interaction as well. Following a short discussion of melodic whistling, we provide an in-depth analysis of two types of non-melodic whistling, which we will call the "tonal whistle" and the "gliding whistle", showing that non-melodic whistles can be deployed as nonlexical sound objects with recurrent forms and functions in social interaction. In this sense, they are well-integrated communicative signs in a grammar of embodied face-toface interaction (Reber \& Couper-Kuhlen, 2010; see also Reber, 2012, 2018, in press). The analysis of non-melodic whistles as non-lexical sound objects gives us insight not only into our understanding of language (and its margins), but also into what constitutes the fundamental unit of interaction, the TCU. As we will see, these two issues are closely intertwined.

\subsection{Non-lexical sound objects at the margins of language}

In linguistics, not only paralinguistic sounds but also primary interjections have commonly been treated as marginal to language because their sound shape is often not phonemic (as in clicks or whistles), and because they do not have a proper semantics (as, e.g., most nouns and verbs do) nor do they seem to be syntactically functional as are, e.g., nouns or verbs in clauses. ${ }^{3}$ To cite some relevant examples from recent

3. In linguistics, there is a general distinction between primary interjections (e.g., oh, ah oder ugh), and secondary interjections (e.g., oh my God, good heavens). This distinction originated with work by the German psychologist Wilhelm Wundt at the beginning of the $20^{\text {th }}$ century, in which he describes primary interjections as remnants of non-linguistic Naturlaute (natural sounds) which interrupt speech for the expression of emotion. On the 
linguistic work on English, Goddard (2014) considers secondary interjections such as Shit! Fuck! Christ! as "identical to other words", whereas primary interjections are described as "Word-like" (e.g., Wow! Yuck! Gee!) or only "Noise-like" if they come with a non-phonemic sound structure (e.g., Ugh! Psst! Tsk tsk!) (2014: 54). According to Wharton (2003), only derivations of interjections, e.g., to wow or yucky, constitute "language proper" and serve to say something. At the other extreme of the continuum, ugh, ow, oh, and ah are placed next to bodily movements such as "shiver" and "smile", which are functional in "showing" something in a "natural" fashion (Wharton, 2003, p. 210). Yet these descriptions conflict with both historical and cross-linguistic findings: Historically, seemingly "word-like" interjections have developed through language change, i.e., they stem from linguistic structure and thus represent linguistic structures: For instance, Gee! goes back to the proper name Jesus! (Gehweiler, 2008), and German oje! to oh mein Jesus! (Nübling, 2001). Cross-linguistic evidence shows that interjections are not "natural" but arbitrary linguistic signs which are not necessarily equivalent across language boundaries: It has been argued that English $o h(/ ə \mho /)$ not only translates to German oh (/o:/) but also to ach and achso (Couper-Kuhlen, 2009; Golato, 2012; Golato and Betz 2012), although more research is needed to explore the full picture (Reber, 2018).

In keeping with early research which studied vocal tract sounds in their home environment of social interaction (e.g., Heritage, 1984; Jefferson, 1984a), we have argued widely for the study of non-lexical sounds from a "bottom-up" perspective (CouperKuhlen, 2009; Reber, 2012, Reber \& Couper-Kuhlen, 2010). The study of the sounds of

other hand, secondary interjections are treated as linguistic forms of pure emotional expression (Wundt, ${ }^{3} 1911$, p. $320-321$ ). 
naturally occurring interaction has revealed a formal and functional continuum between non-lexical and lexical sounds. For instance, the phonetician Pompino-Marschall (2004) identifies a formal continuum of what he calls "interjectional utterances" (interjektionale Äußerungen) in German, including what are known as "fillers", e.g. $\ddot{h}(m)$, and primary and secondary interjections, e.g., $n(a) j a$, toitoitoi and Mensch. These interjectional utterances range between the two extremes of "quasi unarticulated vocal gestures" (quasi unartikulierten Lautgebärden) and "canonically correct pronunciation of underlying words" (kanonisch [korrekte] Aussprache des zugrunde liegenden Wortes, PompinoMarschall, 2004, p. 82). He argues that what are heard as quasi unarticulated vocal gestures in fillers constitute a display of weak articulatory tonus (artikulatorischer Tonus, Pompino-Marschall, 2004, p. 81) accompanied by a high speech tempo. In other words, their production is due to the articulatory constraints of spontaneous speech (rather than being a remnant of animal sounds).

In line with Pompino-Marschall's findings, we have proposed a functional continuum ranging from non-lexical sounds - including clicks and whistles - to more lexical vocal track sounds such as, e.g., $a h$ and $o h$, on the grounds that they fulfil similar conversational tasks in English interaction. The present study provides additional evidence for such a continuum.

\subsection{Non-lexical sound objects as TCUs}

According to Sacks, Schegloff, and Jefferson's classical definition, the turn can be composed of a single word, a phrase or a clause (Sacks et al., 1974, p. 702). Their examples illustrate that primary interjections can function as single-word turns:

Extract 1: “Huh?” as a TCU [NB:I:5:4] (Sacks et al., 1974, p. Fn 12)

$\begin{array}{lll}1 & \text { GUY: } & \text { Is Rol down by any chance dju know? } \\ 2-> & \text { EDDY: } & \underline{\text { Huh? }}\end{array}$ 
Huh? in line 2 serves as an open-class repair initiator (Drew, 1997): It treats the whole of Guy's prior turn Is Rol down by any chance dju know (line 1) as problematic. ${ }^{4}$ There follows a transition relevance place (TRP) and a smooth transition back to Guy, who now repairs his original turn to Is uh Smith down? (line 3). It is this non-delay of a nextpositioned turn which serves as evidence for the sound object Huh? being treated as a TCU by participants:

We may note that it is empirically evident, from sequential materials, that projectability is the case; i.e., we find sequentially appropriate starts by next speakers after turns composed of single-word, single-phrase, or single-clause constructions, with no gap -- i.e. with no waiting for possible sentence completion (Sacks et al., 1974, Fn 12).

Drawing on Sacks et al. (1974), from which the example sentence in Figure 1 below is taken, Lindström (2006) is concerned with the organization of clausal TCUs in conversation. His examples suggest that lexical sound objects can be deployed as presegments (m:m) and post-segments (hunh) of possible clausal turns (cf. also Culpeper \& Kytö, 2010; Schegloff, 1996, on this point), and that they have the potential to be prosodically integrated.

@@Insert Figure 1@@here

Figure 1: Topological model for turn and/or TCU organization (Lindström, 2006, p. 83) This raises the question of whether all sound objects which are treated as TCU cores (huh?) (but not necessarily pre-and post-segments) must be lexical. Based on evidence

4. See also Dingemanse, Torreira, and Enfield, 2013, who argue that $h u h$ has the status of a universal word. 
that non-lexical sound objects such as the "tonal whistle" and the "gliding whistle" can function to implement both initiating and responsive actions, we will argue that this is not the case. Note that it has recently been established that social actions can be achieved and made relevant through the full range of embodied resources in space (e.g., Keevallik, 2013), even forming "nonverbal action sequences," i.e., courses of actions which are achieved through physical actions only (Levinson, 2013, p. 125). Gerhardt and Reber (2019) conclude:

Actions in embodied activities are not necessarily built exclusively through turns or turn-constructional units (TCU), i.e. through talk, but also involve non-verbal resources whose form cannot be described solely in terms of TCUs (Gerhardt \& Reber, 2019, p. 5).

In this paper, we will propose a perspective on TCUs as consisting not only of lexical, phrasal, and clausal units in their core, but also of non-lexical items such as nonmelodic whistles. This implies that words, phrases, clauses as well as non-lexical sounds can serve as speaker resources for action formation and ascription.

\section{Data and methodology}

Our study is based on a wide range of audio and video recordings of American English and British English telephone and face-to-face conversations, which have been combed through for all occurrences of communicative whistles. ${ }^{5}$ Exemplars have been transcribed in their context of occurrence, for the most part according to GAT II (Couper-Kuhlen \& Barth-Weingarten, 2011) - and where relevant - Mondada's (2014)

5. The data used for our analysis were collected with informed consent and names, images and other identifiers have been anonymized. In the case of the NB corpus, which was compiled in the 1960s, the origins are unknown. 
conventions for multimodal transcription. Our methodology is informed by Interactional Linguistics (Couper-Kuhlen \& Selting 1996, 2001, 2018), meaning that we use the descriptive tools of Linguistics, the micro-analytic approach of Conversation Analysis and the framework of Contextualization Theory to analyze linguistic structures in ongoing social interaction.

Our analysis identifies two basic forms of whistling in social interaction: First, what we call melodic whistling, that is, when participants whistle the tune of, for instance, a familiar song, to display their non-participation in, and/or lack of availability for focussed interaction. And secondly, what we call non-melodic whistling. Nonmelodic whistling can be found in initiating actions when participants summon, for instance, domestic animals or people. They are implemented with "tonal whistles" in our data. On the other hand, non-melodic whistling can also be used in responsive actions, when participants treat a prior informing as involving a breach of norm. These are shaped as "gliding whistles". Our paper describes both melodic and non-melodic whistling but focuses primarily on non-melodic whistles.

\section{Melodic whistling}

Melodic whistling involves producing melodies or tunes which may or may not be immediately recognizable. Here is a case where Guy, who is talking to his golf partner Jon on the phone, does a rendition of "Whistle while you work" as he waits for Jon to look up the number of a local golf course in his telephone book.

Extract 2: "Whistle while you work" (NB 01)

((Guy has called his friend Jon to arrange a golf date for the next day. In this excerpt they are trying to decide which golf course to go to.))

1 GUY: have you gotta PHONE number for: san juan? $\mathrm{h}$ 


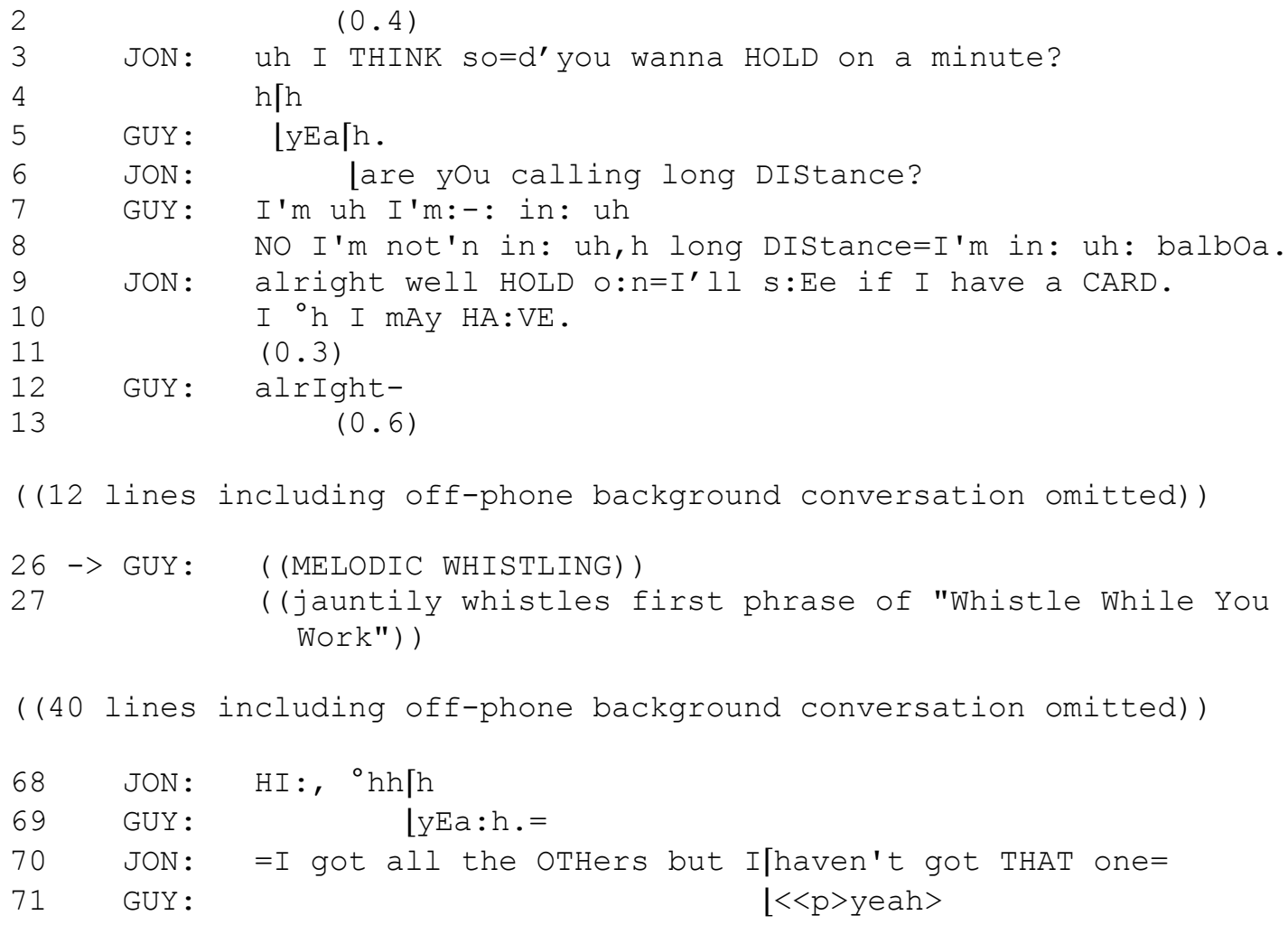

In our data, melodic whistling is a way of actively maintaining "non-participation" (Stevanovic 2013). In (2) it displays that although Guy is linked to Jon through the telephone wires, he is not engaged with him in focussed interaction. Yet the whistling makes it hearable to Jon that Guy is still connected at the other end of the line.

As Extract (3) shows, melodic whistling can also be used to establish that a participant is not available for focussed interaction. In this case the whistling accompanies physical withdrawal from engagement. Here three housemates (Alice, Bill, and Dan) are cooking a meal together. In the multimodal transcription, bP stands for Bill's bodily position, dH for Dan's head movements, and dW for Dan's bodily movements.

\section{Extract 3: "Sausages" (RCE09_UK Housemates II, 7.05) ${ }^{6}$}

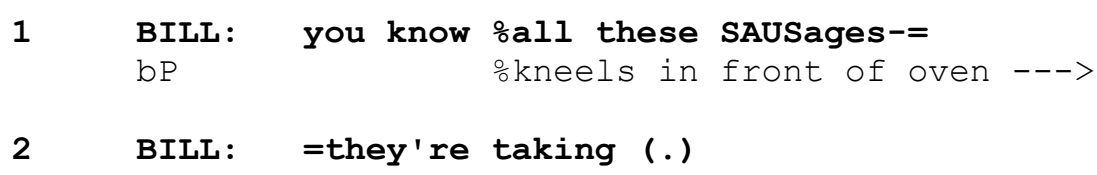

6. Our thanks to Giovanni Rossi for sharing this data extract with us. 


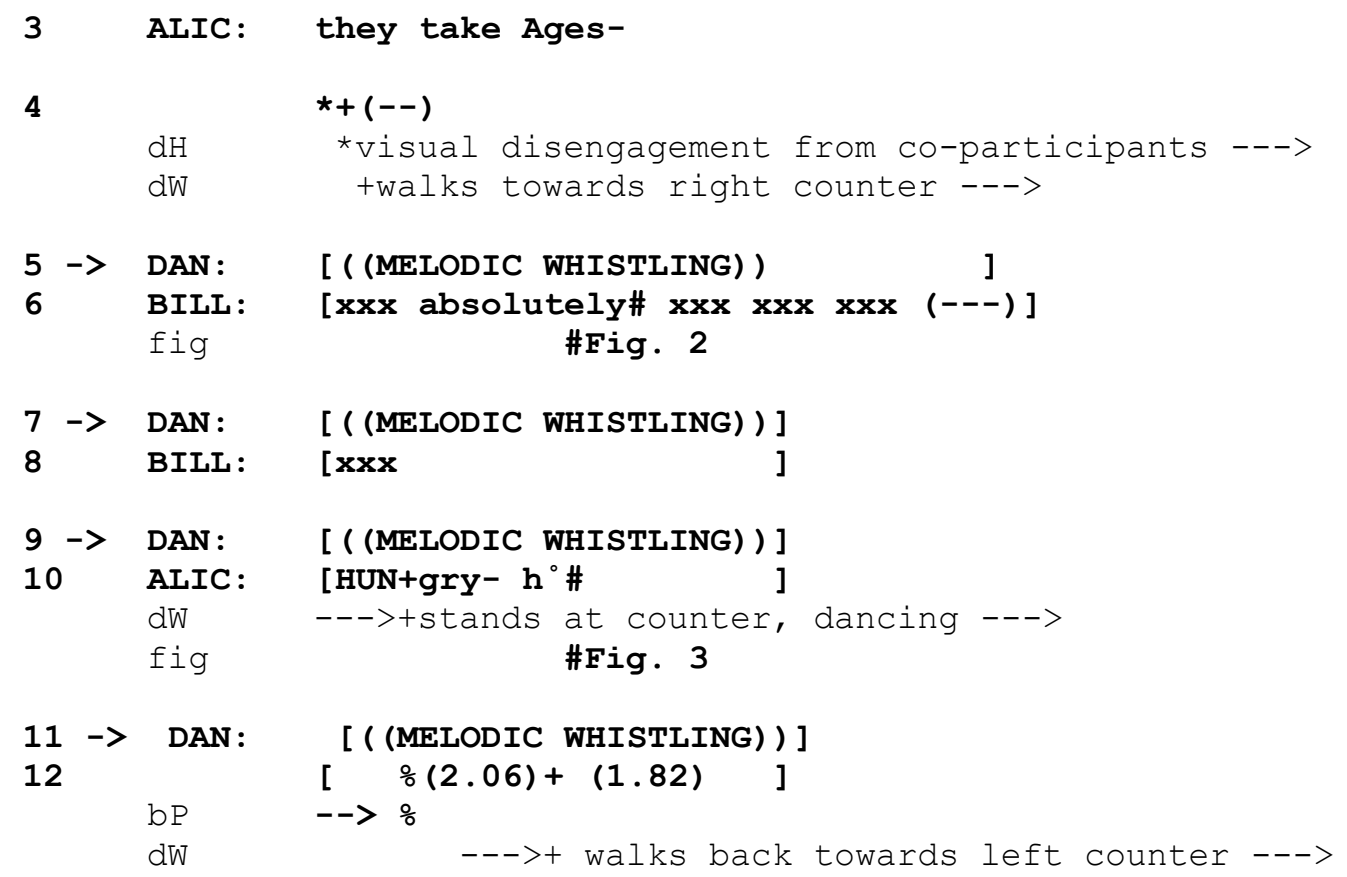

17 ALIC: micro*+wave-

$\mathrm{dH} \quad--->$ *

$\mathrm{dW} \quad--->+$

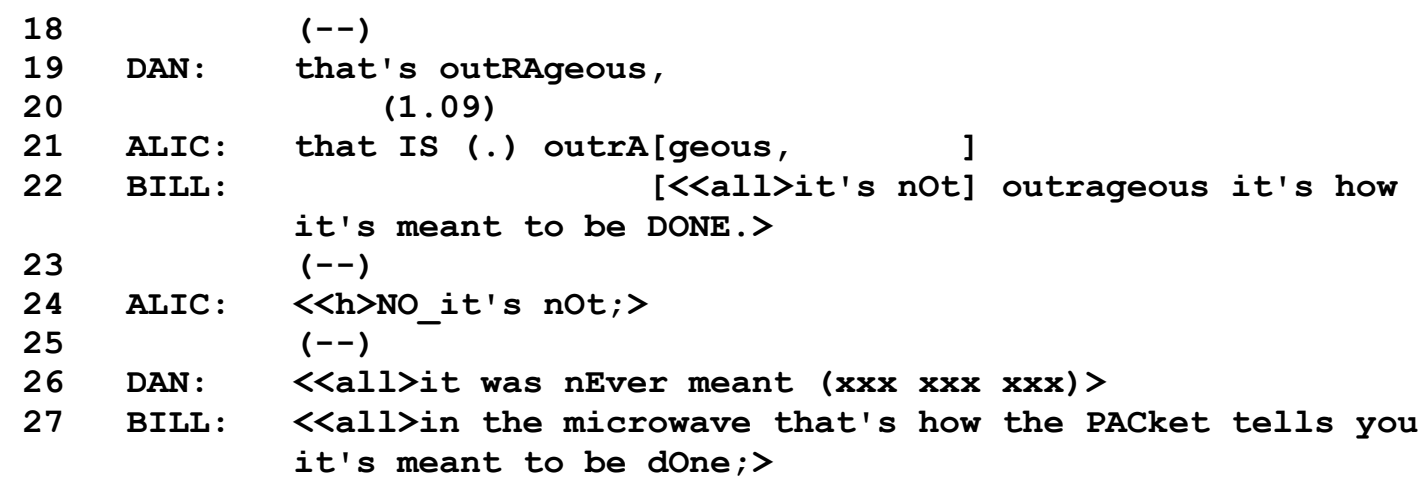

Dan takes a piece of aluminum foil out of the drawer, while Alice and Bill are complaining about how long the sausages take (lines 1-3). There follows a pause, during which Dan crosses the kitchen and walks towards the right-hand counter, showing 
visual disengagement from his co-participants (line 4). Dan next begins to whistle a tune. A split second later, Bill begins to talk, looking into the oven, with Alice being positioned towards him. (lines 6-8, Fig. 2). Although line 6 is partly inaudible, Bill seems to expand on the complaining sequence, affiliating with Alice's prior talk.

\section{@@Insert Figure 2 here@@}

Figure 2: Dan crosses the room, whistling and with visual disengagement (line 6) While standing at the counter, Dan continues to whistle in overlap with more talk (another complaint) and accompanies it with dancing moves (lines 9-10, Figure 3).

\section{@@Insert Figure 3 here@@}

Figure 3: Dan dances at the counter, whistling and displaying visual disengagement (line 10)

Doing some more whistling in the clear, Dan walks back to the left-hand counter to open a drawer (lines 11-12). When he stops whistling, Alice produces another complaint (line 13). Note that Dan shows continued visual disengagement from his participants (Figure 4).

@@Insert Figure 4 here@@

Figure 4: Dan opens drawer, showing visual disengagement (line 15)

It is only in orientation to the production of the second-person address form you in Alice's next complaint (line 16) that Dan briefly moves his head to gaze at her (Figure $5)$.

Although Alice's reference here is to Bill, Dan's gaze behavior and his lack of whistling here signal renewed availability for interaction, and in fact he now joins in the 
mocking complaint about Bill making mashed potatoes in the microwave (lines 19 and 26).

@@Insert Figure 5 here@@

Figure 5: Dan orients his gaze towards Alice (line 16)

We interpret Dan's melodic whistling in Extract (3) as establishing that at the moment he is not available for focussed interaction. This is in line with the physical withdrawal and visual disengagement from his participants, maintained before and during his whistling. Only once melodic whistling is discontinued and visual contact with Alice reestablished does Dan again become an engaged participant in the interaction.

\section{Non-melodic whistling}

In contrast to melodic whistling, non-melodic whistling involves conventionalized contours that are deployed in the service of specific social actions, including summoning (e.g., a dog, a horse, or a person) and - most frequently - responding appreciatively to informings that involve a breach of norm.

\subsection{The tonal whistle}

In our data one type of non-melodic whistling is deployed by participants to summon non-attentive domestic animals and people. ${ }^{7}$ The type of whistle used in summoning tends to be short and sharp. It involves typically one tone or at the most two.

7. Presumably cat-calls would belong in this category, although in addition to summoning, they incorporate an element of appreciation or aggression as well. We do not have any examples of cat-calls in our collection. 
Here is an example of summons whistling with a single sharp tone. It is taken from a video recording of a face-to-face conversation at a family home. Since Maggie, the speaker who produces the whistle, is off camera at the time of the recording, no stills are provided.

Extract 4: "Chloe” (Camp Reunion Part III, 12.47)

((Sue has been telling her niece Linda about the man who works as her house cleaner. Maggie, Sue's grown daughter, reports that her mother tried to get her to date him but Sue explains that she later realized the man does not have any money. Chloe is

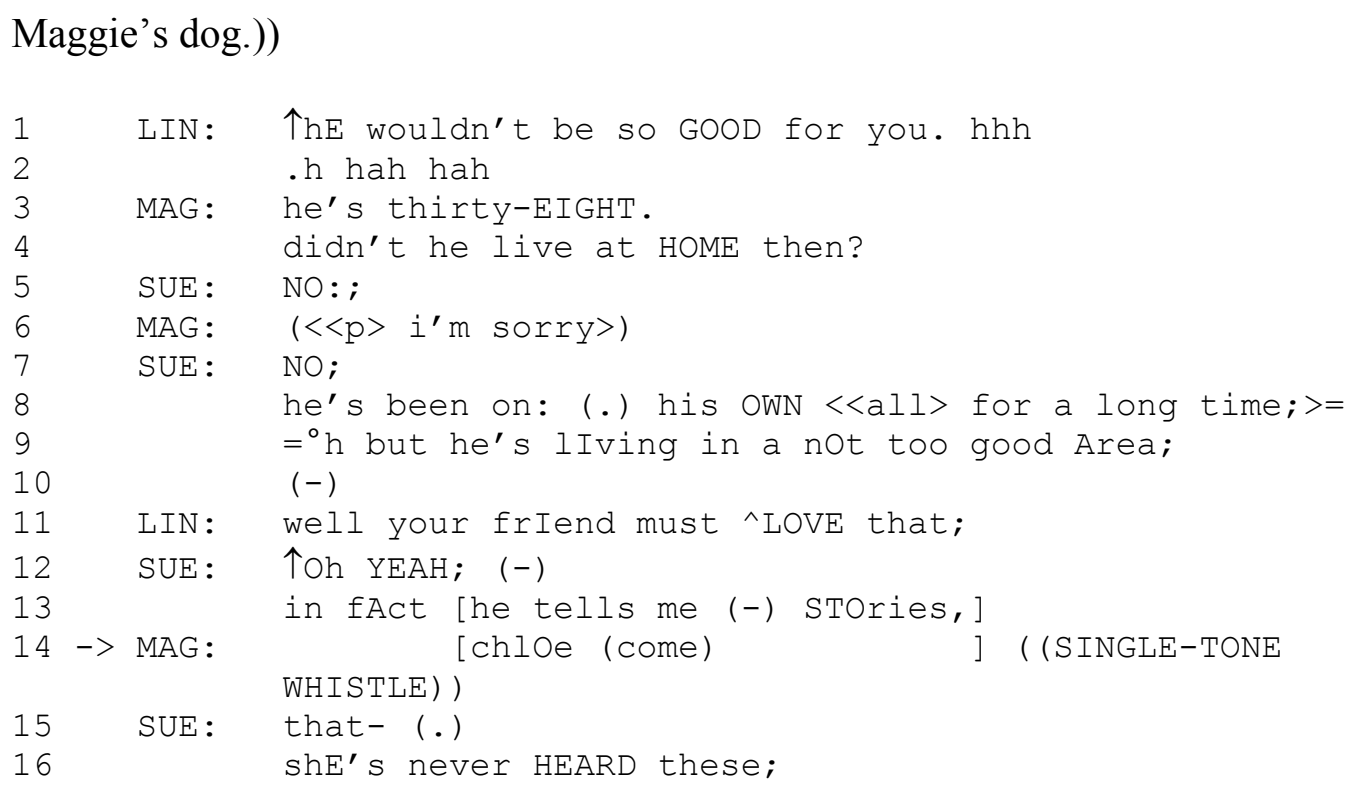

As Sue moves to respond to a follow-up question from Linda (line 11), Maggie takes advantage of the altered participation framework to call her dog. She first summons the dog verbally and then uses a sharp, single-tone whistle to call her (line 14). See Figure 6.

@@Insert Figure 6 here

Figure 6: Narrow-band spectrogram of single-tone whistle in Extract (4)

Here is another case of a single-tone whistle, this time used to attract the attention of a non-attentive co-present interlocutor located at some distance from the summoner: 
Extract 5: "Toma cabron"8

((Two construction-site workers are aligning large rebar "cages" so that they can be coupled with "couplers" (cylindrical components). Horacio is above using a wrench to loosen a particular rod and have it descend. Damian is below and has visual access to the coupling site where the two rebar cages meet, so he can tell Horacio if the components have descended enough.

In this extract Horacio tries to hand the wrench down to Damian, saying toma cabron (Spanish "take [this] dude"), but is initially unsuccessful.))

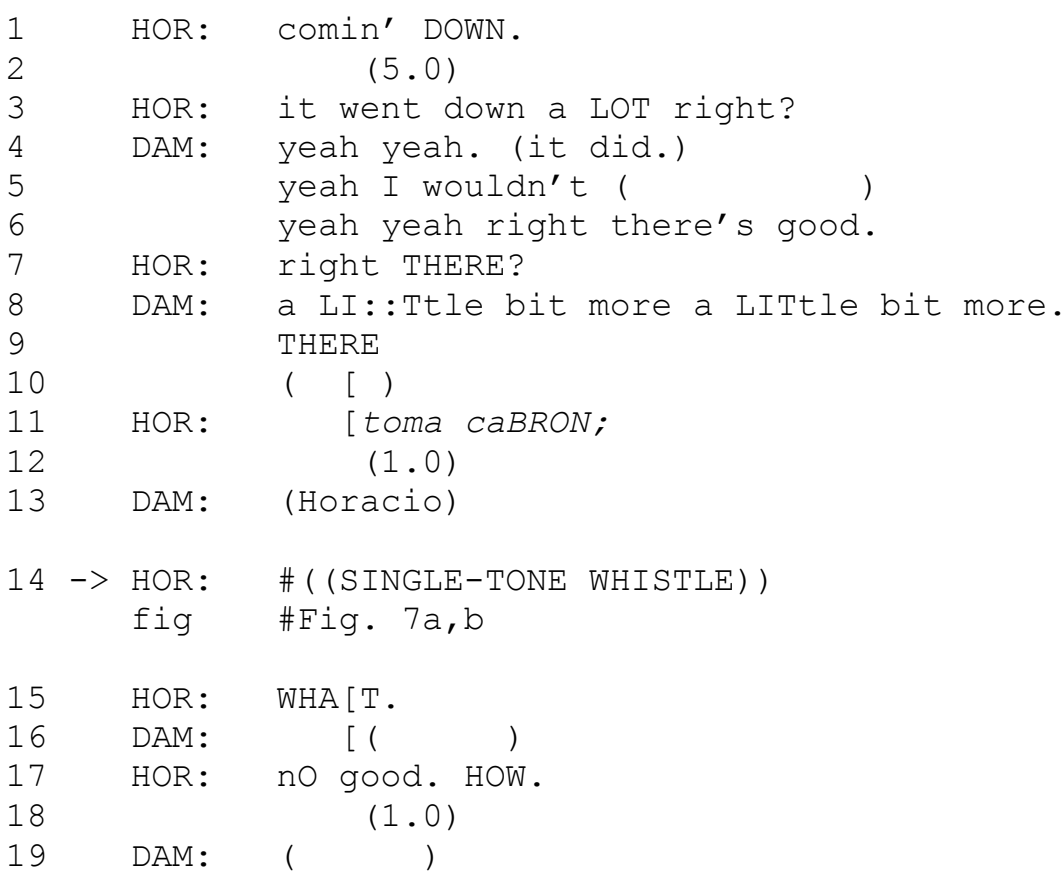

Observe that in order to hand the wrench down to Damian, Horacio directs Damian to "take" it (toma), attaching a term of address cabron "dude" to his directive (line 11). Damian does not attend to this, however, but instead summons Horacio himself (line

8. Our thanks to Elliott Hoey for providing us with this example. 
13). Horacio now produces a sharp and loud single-tone whistle ${ }^{9}$ (line 14 , Figure $7 \mathrm{a}, \mathrm{b}$ ) in pursuit of Damian's attention but then immediately responds to Damian's summons with what (line 15).

@@Insert Figure 7a here@@

Figure 7a: Horacio produces a single-tone whistle to summon Damian

@@Insert Figure 7b here@@

Figure 7b: Damian's bodily orientation during the summons

Another kind of summons whistling uses two tones with the second being approximately three semitomes lower than the first: His tonal configuration when aligned with, e.g., a proper name is known among linguists as the "calling contour" (Ladd, 1996). In the following case the two-tone whistle is used to summon a horse:

Extract 6: "Sheeba" (SBCSAE 56)

((Julie, a horse breeder and trainer, is introducing her horses, Sheeba and Beamer, to her guest Gary.))

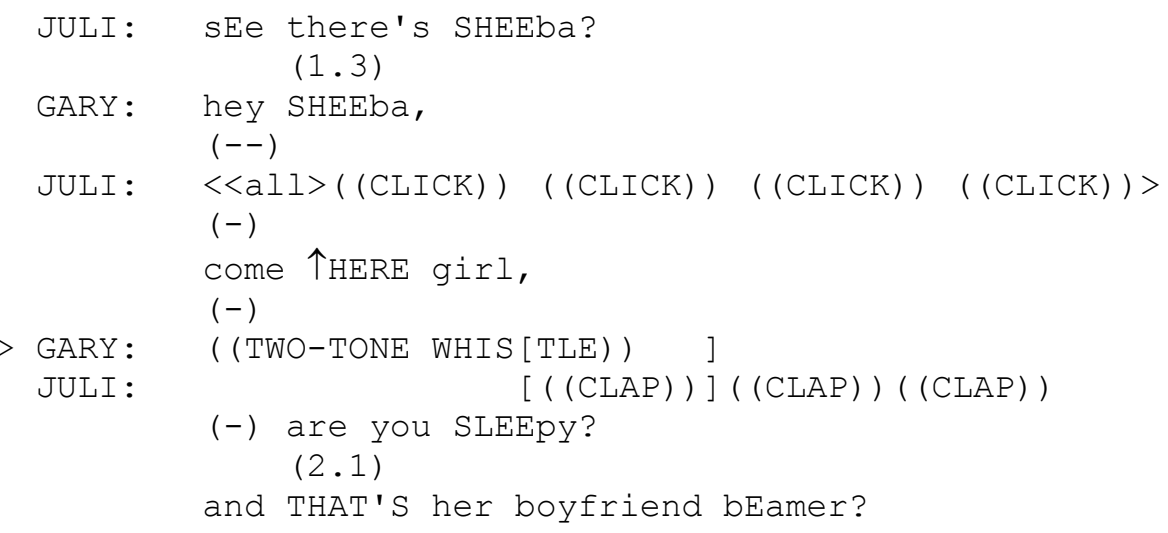

9. This whistle has an offglide but we categorize it as 'tonal' because it is sharp and fast in contrast to ,gliding' whistles, which are smooth and slow. 
The summons sequence begins in line 3, where Gary greets the horse using a greeting formula and the horse's name (hey SHEEba, line 3). After a pause, Julie summons the horse through multiple clicks (line 5) and verbal resources (come $\uparrow H E R E$ girl, line 7). Following another pause, Gary produces a bi-tonal whistle (See Figure 8). In partial overlap, Julie claps three times. We can infer that the use of these multiple summoning practices (lexical and non-lexical) are an orientation to the horse's delayed uptake (are you SLEEpy, line 11).

@@Insert Figure 8 here@@

Figure 8: Narrow-band spectrogram of bi-tonal whistle in Extract (6)

Although more research is necessary, we can provisionally conclude that non-melodic tonal whistling in order to summon pets or people is one of a variety of practices used to perform this action. In all of our cases, mono-tonal or bi-tonal whistling is produced in pursuit of uptake after a verbal summons in which the pet or the person is addressed by a nominal term of address. These terms of address are generally names (with the exception of cabron, which constitutes a non-name term of address).

\subsection{The gliding whistle}

A second type of non-melodic whistling has a shape that is distinct from the tonal whistle: It begins on a high tone and glides slowly downwards. Exemplars produced by different speakers on different occasions are recognizable as belonging to the same type.

The most common function of this type of gliding whistle in our data is in response to a news informing that implies a breach of norm. A common practice to convey a breach of norm is the use of numerical references (Wilkinson \& Kitzinger, 2006). In what follows, we will exemplify how gliding whistles are deployed to respond to various kinds of informings. 
We begin with a case in which an informing is built to be impressive. This informing contains a numeral, produced in response to Laura's query how far do you WALK. (0.6) Usually, directed to Donna, who has just arrived at the gathering in a jogging outfit:

(7) "Five miles" (Farmhouse_2:12) ${ }^{10}$

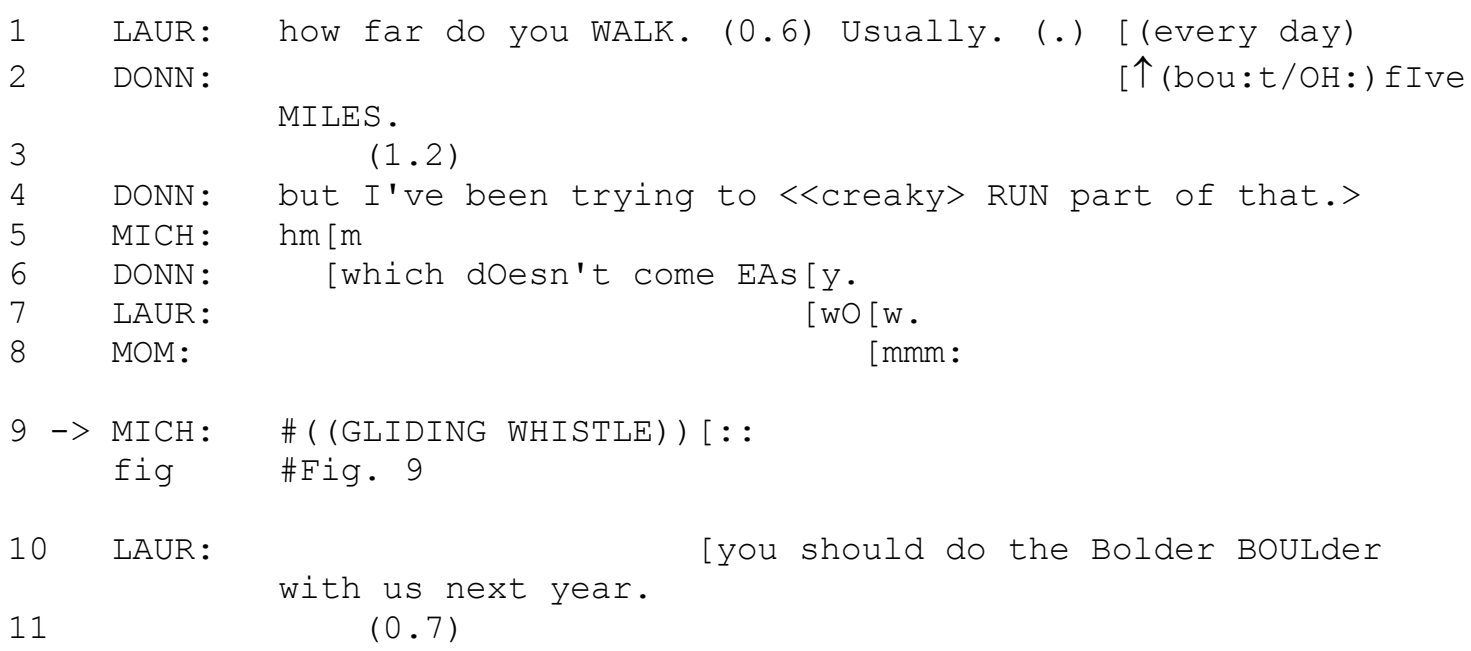

When Donna reports that she walks five miles every day, this is not treated by the participants as especially noteworthy (see the $1.2 \mathrm{sec}$. silence in line 3 ). However, when Donna adds that she tries to run part of this distance (line 4$)^{11}$ and that this is not easy for her, her informing is transformed into a report of an even more noteworthy effort (line 14). Now all three participants respond affectively, Laura with $w O w$, Mom with $m m m$;, and Michelle with a gliding whistle (lines 7-9, Figure 9). The gliding whistle then is, like the particle wow, one resource for displaying appreciation in response to an informing that is built to impress the recipient(s).

@@Insert Figure9here@@

10. Our thanks to Barbara Fox for providing us with access to this example.

11. The phrase $r$ Un part of that is produced with creaky voice. 
Figure 9: Michelle, who sits at the back on the right, produces a responsive gliding whistle.

While in (7) it is a report of the speaker's stance towards a quantification that leads to a gliding whistle response, on other occasions it is the quantification itself which conveys the extremity of a state of affairs and makes "gliding whistle" a relevant type of response:

Extract 8: "Between twenty and twenty-five horses" (SBCSAE 56_14.36)

((Julie, a horse breeder and trainer, is showing her barn to Gary, who has just sold his wife's pony to her.))

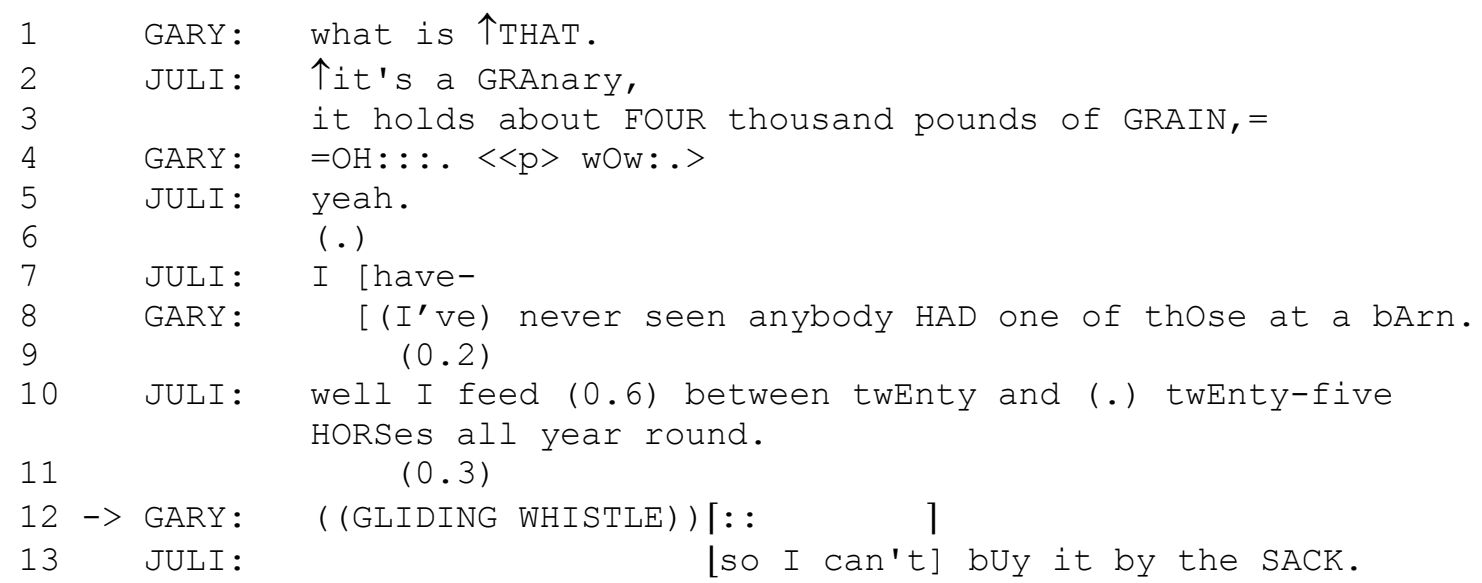

Following a lengthened news receipt $O H:::$ (Heritage 1984), Gary displays appreciation of the size of Julie's granary with a soft $w O w$ (line 4). He goes on to profess never having seen one that size in a barn (line 8$).{ }^{12}$ In other words, Gary treats the size of the granary as a "breach of norm", which Julie now accounts for by invoking the number of horses she must feed. While she could have said "I have to feed a lot of horses every year", she instead specifies the number of horses she feeds: between twEnty and twEnty-

12. It may be worth noting that earlier in the conversation Gary has explained to Julie that he builds barns for a living: he is thus an expert in this domain. 
five HORses and adds an extreme-case formulation: all year round (line 10). It is this information that Gary receipts with an appreciative gliding whistle. See Figure 10.

@@Insert Figure10here@@

Figure 10: Narrow-band spectrogram of gliding whistle in Extract (8)

A gliding whistle is neither inherently positive nor inherently negative in valence. In (7) it was used to respond to something treated as a tribulation (running a lengthy distance "which dOesn't come EAsy", line 6). But in (9) it is used to receipt an informing that is framed as positive in nature:

Extract 9: “Conveyancing” (HOLT:M88:2:4 A)

((Hillary is telling her cousin Mark about her future son-in-law Mike, who is going to do the conveyancing for the property he and Hillary's daughter are about to purchase.))

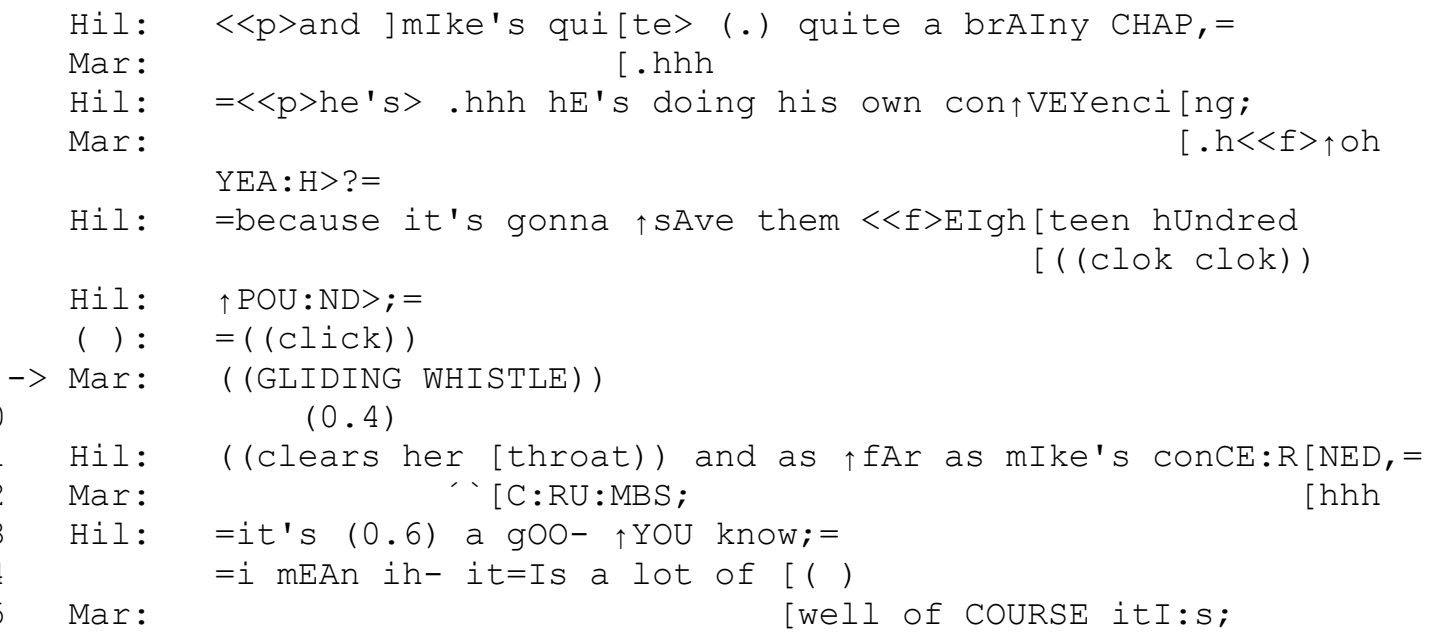

Here too Hillary could have said about her son-in-law's conveyancing “it's gonna save them a lot of money", but instead she specifies the precise amount $<<f>$ EIghteen $h U n d r e d \uparrow P O U N D>$ (lines 5 and 7) in a prosodically "pumped up" fashion (Wilkinson \& Kitzinger, 2006). This invites Mark to appreciate it, which he does with a well-timed gliding whistle (line 9). See Figure 11. Note that after a brief pause, Mark goes on to produce another mark of appreciation, the formulaic expression CRUMBS, in line 12. 
@@Insert Figure11 here@@

Figure 11: Narrow-band spectrogram of gliding whistle in Extract 9

\section{The gliding whistle compared to lexical response tokens}

As in Extract (7) above, gliding whistles often appear together with lexical response tokens such as wow. If they are produced by the same speaker, the lexical token on occasion follows the gliding whistle in a separate turn-constructional unit: this is what we saw happening with crumbs in (9). Yet on other occasions, the lexical response token precedes the gliding whistle. Here is a case in point:

Extract 10: "Impound the horse" (SBCSAE 56_7:36-8:22)

((Julie has been explaining to Gary what a legal brand inspection for a horse is and why it is important.))

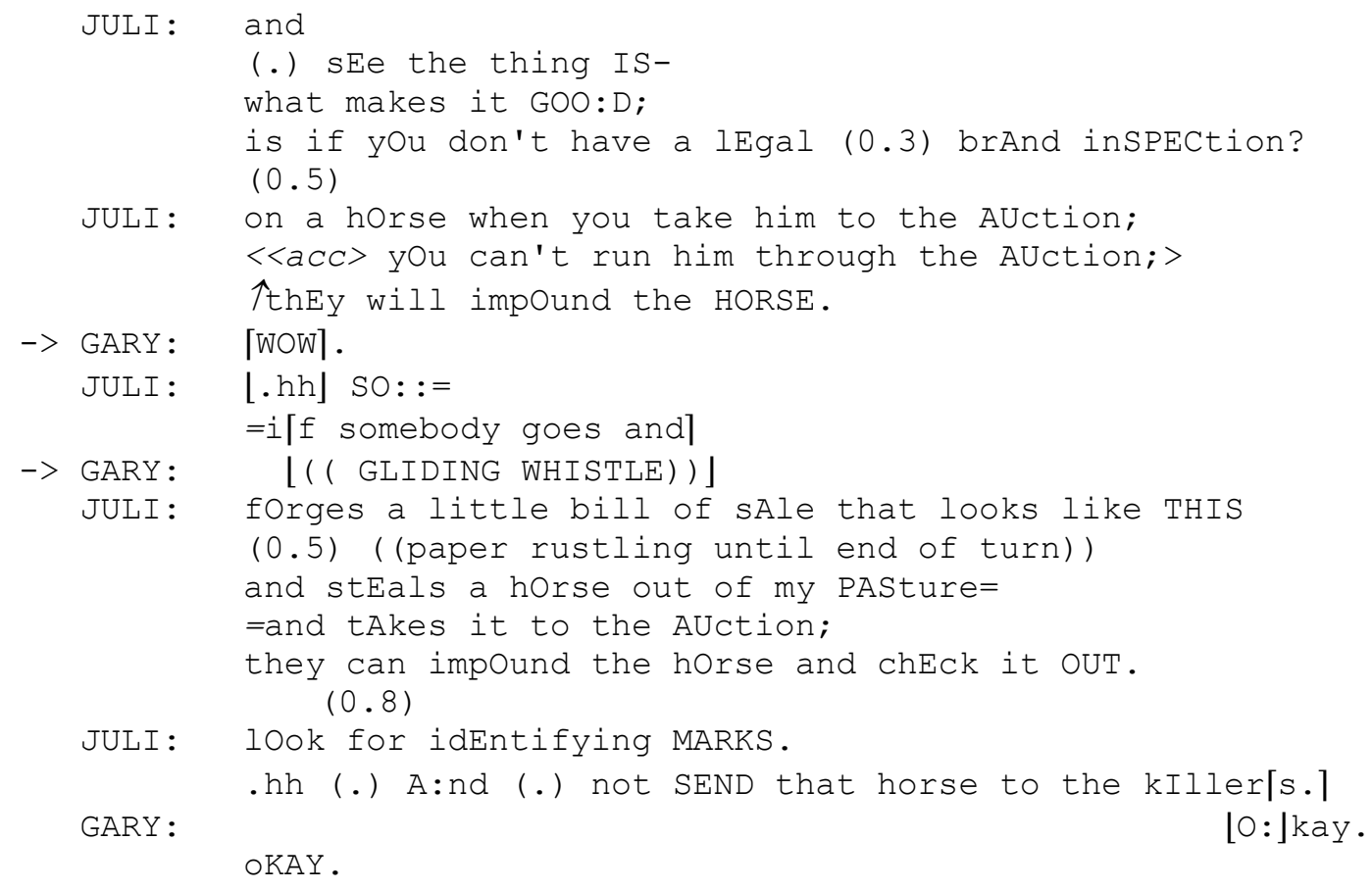

In response to Julie's shocking information that a horse will be impounded at an auction if there is no legal brand inspection for it, Gary first produces a WOW (line 9) and then, before Julie can pursue continuation of her turn, a gliding whistle (line 12). Both 
responses target the unexpected breach of norm implied by Julie's dramatic impOund the hOrse (line 8).

As Extract (10) suggests, it could be argued that gliding whistles and lexical tokens such as wow accomplish much the same work: they both express appreciation of something that is treated as "out of the ordinary". Like wow, a gliding whistle is not valenced either positively or negatively (Local \& Walker, 2008). And like wow, the contour of a gliding whistle, beginning on a high tone and falling downwards, resembles one possible pitch contour for wow, although it is produced at a much higher frequency and without vibration of the vocal folds.

Yet a more careful comparison of wow and the gliding whistle as used, e.g., in (10) above cautions against overstating their similarity. Note, for instance, that Julie produces an inbreath after her drastic announcement they will impOund the hOrse (line 8), done as a source of surprise in the sense of Wilkinson and Kitzinger (2006). This leaves space for Gary to produce wow in the clear (line 9). Julie does not recommence speaking until Gary's wow has come to completion (see Goodwin, 1986, for similar cases). But Gary produces his subsequent gliding whistle (line 12) in overlap with Julie's turn continuation, which is launched by a lengthened so:: (Raymond 2004). This whistle overlaps fully with what Julie says next if somebody goes and, yet neither speaker cuts off or recycles their turn. That is, the co-participants do not treat the overlapping gliding whistle as making recycling or repair necessary (Schegloff, 1987). This is a pattern encountered again and again in our data: overlap appears to be more tolerable with a gliding whistle than with a lexical response token such as wow.

At the same time, a gliding whistle can be used as a resource to build a freestanding turn-constructional unit. In (7) - (9), for instance, the whistle is produced at a TRP and is well-timed with respect to the turn it is responsive to. However, in two 
of these cases, (7) and (8), a co-participant sets in with their next turn before the whistle has been completed. This may be attributable to the fact that the end of a gliding whistle is difficult to project before it actually happens: falling tones may flatten out and be prolonged indefinitely. Therefore, the terminal overlap between the gliding whistle and a coparticipant's next turn (Jefferson 1984b) may come about inadvertently if the whistler lengthens their sound object.

Yet there are several instances in our data where the overlap between a gliding whistle and talk by other is an achievement brought about by the co-participant pursuing a turn regardless of the fact that the interlocutor has begun a responsive whistle. This is what happens in the following extract:

Extract 11: "Twenty thousand acres" (SBCSA 56_10.49)

((Julie is telling Gary about how she uses thirty-two English foxhounds at her club to go foxhunting.))

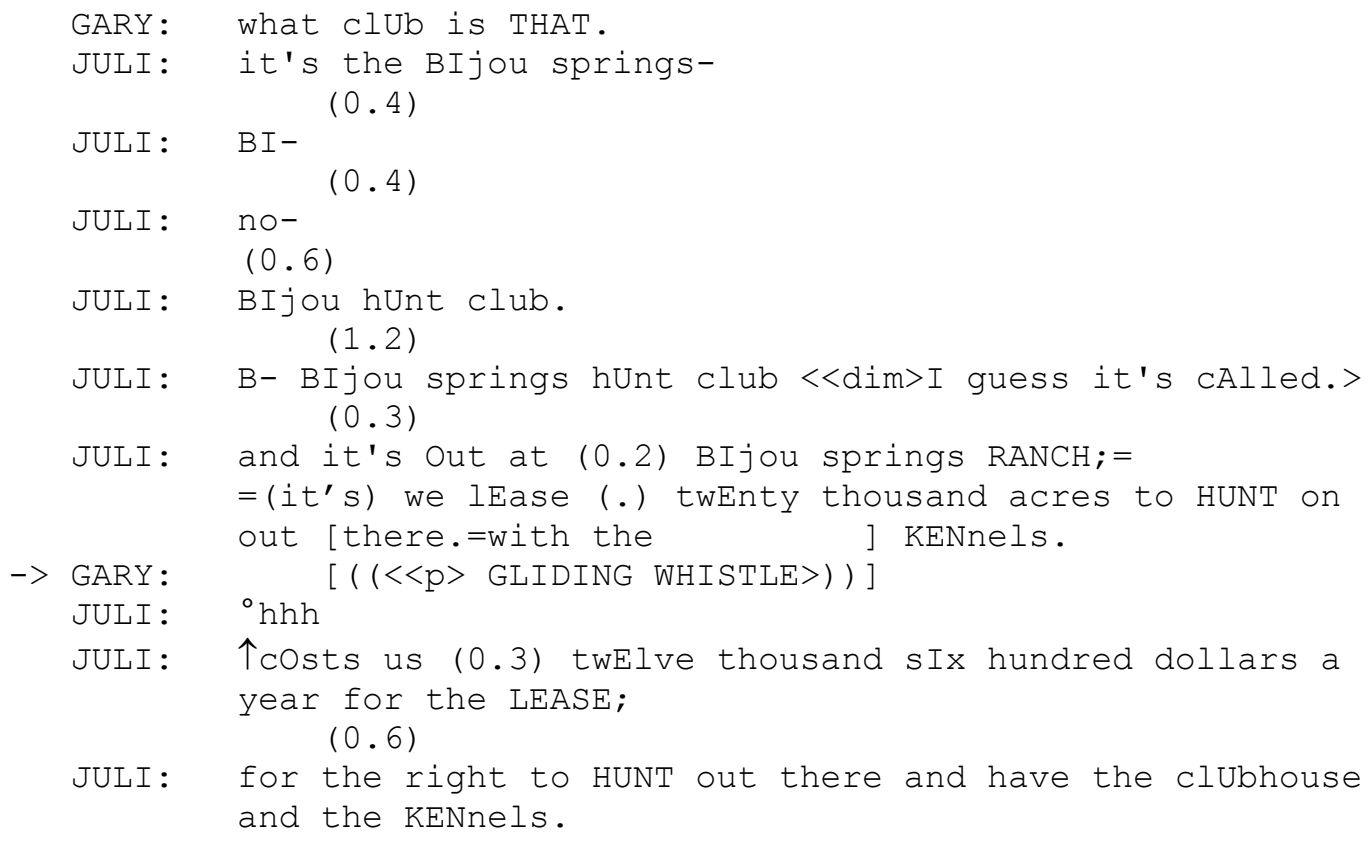

The gliding whistle in line 15 is produced in orientation to a projectable TRP after HUNT on out there (lines 13-14). But although Julie can clearly hear Gary's whistle, 
she nevertheless proceeds to add an increment: with the KENnels (line 14), thus talking in overlap with Gary's whistle. Neither participant orients to the fact that they are speaking in overlap. In fact, it might even be doubted that they are both "speaking": actually one is speaking while the other is (softly) whistling. At the completion of her turn (line 16), Julie appears to monitor for a more substantial (lexical) token of appreciation, given the fact that she has just announced that she leases an inordinately large acreage of land. When this is not forthcoming, she proceeds to produce another "out of the ordinary" number, namely what it costs to lease the land (line 17). Again she monitors for some token of appreciation (line 18), which Gary withholds.

The data thus lead us to the (preliminary) conclusion that a gliding whistle is in many ways equivalent to a lexical response token such as wow in terms of what it is used to accomplish and the way it can build a freestanding turn-constructional unit. But at the same time, a gliding whistle is only a partial equivalent to a response token such as wow in terms of how participants orient to its turn-taking potential (cf. also Goodwin, 1986). A gliding whistle is often produced in overlap; moreover, when overlap with a gliding whistle occurs, no recycling or repair ensues.

\section{Implications and Challenges}

In our study, we have distinguished between three formal types of whistling in English social interaction: melodic whistling, the non-melodic tonal whistle, and the non-melodic gliding whistle. Each formal type is used for a specific interactional purpose.

The analysis of melodic whistling confirmed previous research: melodic whistling appears in the form of tunes that may be recognizable or not for participants. It is deployed as a display of non-participation in and/or lack of availability for focussed interaction in both telephone and face-to-face interaction. This kind of whistling strongly contrasts with non-melodic whistles, which constitute sound objects 
characterized by a set of constant and recognizable forms and functions. Non-melodic whistles are used to implement conventionalized, sequentially situated actions, both initiating and responsive. Unlike melodic whistling, which has been shown to be interchangeable with humming (Stevanovic, 2013), non-melodic whistles cannot be replaced by hums.

When used as a summons, the non-melodic whistle is tonal: it tends to be short and sharp, typically involving one tone or at the most two. Non-melodic responsive whistles, on the other hand, are produced as slow glides with a falling contour. There is some gradience in terms of how high the initial pitch peak goes, ${ }^{13}$ and in contrast to non-melodic initiating whistles, they can be produced with a lax, "whispery" quality. ${ }^{14}$

As an initiating action, the non-melodic tonal whistle generally serves as a summons of non-attentive domestic animals and people. Our data suggest that this sound object is produced in a position following a verbal summons or term of address, in pursuit of a response. In these environments, tonal whistles form separate TCUs. On the other hand, the gliding whistle is used systematically to build responsive turns following informings that contain a numerical reference or some other detail that is treated as impressive or shocking. Here the prior turn has often been set up to be impressive by incorporating extreme-case formulations, intensifying emphasis (Ogden, 2012; Reber, 2012), and/or “punched up” prosody (Wilkinson \& Kitzinger, 2006). When they are produced as responsive actions, the status of whistles as separate TCUs seems less clear, but this ambiguity may be part of their usefulness.

13. The span covered by the gliding whistles in our collection ranges from 4 to 12 semi-tones.

14. The "whispery" quality presumably comes from the whistle being softer with more friction at the lips (p.c., Richard Ogden). 
Our analysis has revealed that the sound object "gliding whistle" can co-occur with the lexical token wow in the same responsive environments. Like wow as described by Local and Walker (2008), a gliding whistle displays appreciation (for something positive) or being impressed and on occasion shocked (for something negative or counter to the norm). Although the gliding whistle can build a freestanding TCU, it can also be delivered legitimately in full overlap with ongoing talk. Co-participants who find themselves speaking at the same time as a gliding whistle is being produced do not orient to the overlap as requiring cut-off or recycling. Nor do co-participants always orient to it as a full-fledged response: on occasion they appear to expect a lexical uptake.

In conclusion, we wish to propose that non-melodic whistles constitute conventionalized spoken signs: both the initiating tonal as well as the responsive gliding whistle represent stable form-meaning pairings. Granted, these types of whistle do not have referential semantics nor much phonetic substance (no vowels or consonants). Produced by the speech organs in a way that is similar to speech, they are like clicks, but in contrast to clicks, they do not have an orthographic representation. ${ }^{15}$ We noted that a two-tone whistle is similar to what linguists know as the "calling contour" (Ladd, 1996), i.e., a stylized intonation contour which is associated inter alia with the function of summoning. This contrasts with the "gliding whistle", which has not been acknowledged as a linguistic entity in previous research. Nevertheless, our data suggest that it a conventionalized sign for building responsive turns.

15. It is true that the IPA has a phonetic representation [w]) for 'whistle', but this representation does not necessarily correspond to the sounds observed in our data nor does it capture the difference between a 'tonal' whistle and a 'gliding' whistle. 
We conclude that there is a continuum of sound objects that function as spoken communicative signs, with "gliding whistle" and "tonal whistle" being at one - nonlinguistic - extreme and lexical tokens such as, e.g., the word hey or wow being close to the other, thus reflecting different degrees of lexicality (Figure 12). We conceptualize the entity crumbs as being more lexical than, e.g., hey and wow, because of its etymological origins. ${ }^{16}$

@@Insert Figure 12 here@@

Figure 12: Non-melodic whistling at the margins of language Acknowledgments

An earlier version of this paper was first presented at the panel "Non-lexical vocalizations in interaction", 5th International Conference on Conversation Analysis (ICCA 2018), Loughborough University, UK, 11-15 July 2018. Our thanks to the audience at this panel, the editors, and two anonymous reviewers for their comments.

\section{References}

Busnel, R.-G., \& Classe, A. (1976). Whistled Languages. New York: Springer.

Couper-Kuhlen, E. (2009). A sequential approach to affect: The case of “disappointment”. In M. Haakana, M. Laakso \& J. Lindström (Eds.). Talk in interaction: Comparative dimensions (pp. 94-123). Helsinki: Finnish Literature Society.

Couper-Kuhlen, E., \& Barth-Weingarten, D. (2011). A system for transcribing talk-ininteraction: GAT 2. English translation and adaptation of Selting, Margret et al: Gesprächsanalytisches Transkriptionssystem 2. Gesprächsforschung Online, 12, 1-51.

Couper-Kuhlen, E., \& Selting, M. (1996). Towards an interactional perspective on prosody and a prosodic perspective on interaction. In E. Couper-Kuhlen \& M.

16. Historically, crumbs seems to stem from the mild oath By crum! (https://www.merriamwebster.com/words-at-play/edible-interjections/crumbs). 
Selting (Eds). Prosody in conversation: Interactional Studies (pp. 11-56).

Cambridge: Cambridge University Press.

Couper-Kuhlen, E., \& Selting, M. (2001). Introducing Interactional Linguistics. In M.

Selting \& E. Couper-Kuhlen (Eds). Studies in Interactional Linguistics (pp. 122). Philadelphia / Amsterdam: John Benjamins.

Couper-Kuhlen, E., \& Selting, M. (2018). Interactional Linguistics: Studying language in social interaction. Cambridge: Cambridge University Press.

Culpeper, J., \& Kytö, M. (2010). Early Modern English dialogues: Spoken interaction as writing. Cambridge: Cambridge University Press.

Dingemanse, M., Torreira, F., \& Enfield, N.J. (2013). Is "Huh?““ a universal word? Conversational infrastructure and the convergent evolution of linguistic items. PLOS ONE, 8 (11).

Drew, P. (1997). "Open“ class repair initiators in response to sequential sources of troubles in conversation. Journal of Pragmatics, 28, 69-101.

Gehweiler, E. (2008). From proper name to primary interjection: the case of gee!. Journal of Historical Pragmatics, 9,71-88.

Gerhardt, C., \& Reber, E. (2019). Embodied Activities. In E. Reber \& C. Gerhardt (Eds), Embodied activities in face-to-face and mediated settings: Social encounters in time and space (pp. 3-27), London: Palgrave Macmillan.

Goddard, C. (2014). Interjections and emotions (with special reference to "surprise" and "disgust"). Emotion Review, 6, 53-63.

Goffman, E. (1978). Response cries. Language, 54(3), 787-815.

Golato, A. (2012). German oh: Marking an emotional change of state. Research on Language and Social Interaction, 45, 245-268.

Golato, A., \& Betz, E. (2008). German ach and achso in repair uptake: Resources to sustain or remove epistemic asymmetry. Zeitschrift für Sprachwissenschaft, 27, $7-37$.

Goodwin, Ch. (1986). Between and within: alternative treatments of continuers and assessments. Human Studies, 9, 205-217. 
Heritage, J. (1984). A change-of-state token and aspects of its sequential placement. In J. M. Atkinson \& J. Heritage (Eds). Structures of social action: Studies in Conversation Analysis (pp.299-345), . Cambridge: Cambridge University Press.

Jefferson, G. (1984a). Notes on a systematic deployment of the acknowledgement tokens "yeah" and "mm hm." Papers in Linguistics, 17, 197-216.

Jefferson, G. (1984b). Notes on some orderliness of overlap onset. In V. D'Urso \& P. Leonardi (Eds), Discourse Analysis and natural rhetorics (pp. 11-38), Padova, Cleup Editore.

Ladd, D. R. 1996. Intonational phonology. Cambridge: Cambridge University Press.

Laver, J. (1994). Principles of phonetics. Cambridge et al.: Cambridge University Press.

Keevallik, L. (2013). The interdependence of bodily demonstrations and clausal syntax. Research on Language and Social Interaction, 46 (1), 1-21.

Levinson, S. C. 2013. Action formation and ascription. In J. Sidnell \& T. Stivers (Eds), The handbook of Conversation Analysis (pp. 103-130), Malden, MA: WileyBlackwell.

Lindström, J. (2006). Grammar in the service of interaction: exploring turn organization in Swedish. Research on Language and Social Interaction, 39, 81-117.

Local, J., \& Walker, G. (2008). Stance and affect in conversation: On the interplay of sequential and phonetic resources. Text and Talk, 28(6), 723-747.

Maynard, D. W. (1997). The news delivery sequence: Bad news and good news in conversational interaction. Research on Language and Social Interaction, 30, 93-130.

Meyer, J. (2008). Typology and acoustic strategies of whistled languages: Phonetic comparison and perceptual cues of whistled vowels. Journal of the International Phoneic Association, 38(1), 69-94.

Mondada, L. (2014). Conventions for multimodal transcription. Version 3.0.1. Retrieved from https://franz.unibas.ch/fileadmin/franz/user_upload/redaktion/Mondada_conv_m ultimodality.pdf.

Ogden, R. (2012). Making sense of outliers. Phonetica, 69, 48-67. 
Nübling, D. (2001). Von oh mein Jesus! zu oje! Der Interjektionalisierungspfad von der sekundären zur primären Interjektion [From oh my Jesus! to oh gee! The interjectionalization path from secondary to primary interjection]. Deutsche Sprache, 1, 20-45.

Pomerantz, A. 1986. Extreme case formulations: A way of legitimizing claims. Human Studies, 9, 219-229.

Rialland, A. (2005). Phonological and phonetic aspects of whistled languages. Phonology, 22, 237-271.

Raymond, G. (2004). Prompting action: The stand-alone "so" in ordinary conversation. Research on Language and Social Interaction. 37(2), 185-218.

Reber, E. (2009). Zur Affektivität in englischen Alltagsgesprächen [On affectivity in English everyday conversation]. In M. Buss, S. Habscheid, S. Jautz, F. Liedtke, \& J. Schneider (Eds), Theatralität des sprachlichen Handelns. Eine Metaphorik zwischen Linguistik und Kulturwissenschaften [Theatrality of linguistic action. A metaphor at the interface of linguistics and cultural studies] (pp. 193-215). München: Fink-Verlag.

Reber, E. (2012). Affectivity in Interaction: Sound objects in English. Amsterdam: John Benjamins.

Reber, E. (2018). Interjektionen [Interjections]. In F. Liedtke \& A. Tuchen (Eds), Handbuch Pragmatik [Handbook of Pragmatics] (pp. 229-239). Stuttgart: J.B. Metzler.

Reber, E. (In press). Interjektionen - an den Rändern der Sprache? [Interjections - at the margins of language?]. In M. Elmentaler \& O. Niebuhr (Eds), An den Rändern der Sprache [At the margins of language]. Berlin: Peter Lang.

Reber, E., \& Couper-Kuhlen, E. (2010). Interjektionen zwischen Lexikon und Vokalität: Lexem oder Lautobjekt? [Interjections between lexicon and vocalization: Lexeme or sound object?]. In Deppermann, A. \& A. Linke (Eds), Sprache intermedial: Stimme und Schrift, Bild und Ton [Language intermedially: Voice and writing, image and sound] (pp. 69-96). Berlin: de Gruyter. 
Schegloff, E. A. (1987). Recycled turn beginnings: A precise repair mechanism in conversation's turn-taking organization. In G. Button \& J. R. E. Lee (Eds), Talk and social organization (pp. 70-85). Clevedon: Multilingual.

Schegloff, E. A. (1996). Turn organization: one intersection of grammar and interaction. In E. Ochs, E. A. Schegloff, \& S. A. Thompson (Eds), Interaction and Grammar (pp. 52-133). Cambridge, UK: Cambridge University Press.

Schegloff, E. A. (2005). Whistling in the dark: Notes from the other side of liminality. Texas Linguistic Forum, 48, 17-30.

Shadle, C. (1983). Experiments on the acoustics of whistling. The Physics Teacher, $21(3), 148-154$.

Shadle, C. 1997. The aerodynamics of speech. In W. J. Hardcastle \& J. Laver (Eds), The handbook of phonetic sciences (pp. 33-64). Oxford, UK: Blackwell.

Shosted, R. K. (2006). Just put your lips together and blow? The whistled fricatives of Southern Bantu. Retrieved from http://linguistics.berkeley.edu/phonlab/documents/2006/whistleISSP.pdf

Stevanovic, M. (2013). Managing participation in interaction: The case of humming. Text \& Talk, 33(1), 113-137.

Wharton, T. (2003). Interjections, language, and the "showing/saying" continuum. Pragmatics and Cognition 11,39-91.

Wilkinson, S., \& Kitzinger, C. 2006. Surprise as an interactional achievement: reaction tokens in conversation. Social Psychology Quarterly, 69(2), 150-182.

Wundt, W. ${ }^{3} 1911$. Völkerpsychologie. Eine Untersuchung der Entwicklungsgesetze von Sprache, Mythos und Sitte [Social psychology. An investigation of the developmental laws of language, myth and custom]. Vol. 1: Die Sprache [The language]. Leipzig: Engelmann. 


\begin{tabular}{|l|l|l|l|}
\hline \multicolumn{3}{|c|}{ Possible turn } \\
\hline \multirow{2}{*}{$\begin{array}{l}\text { Pre-segment, } \\
\text { link to prior }\end{array}$} & \multicolumn{2}{|c|}{ TCU core } & $\begin{array}{l}\text { Post-segment, } \\
\text { link to next }\end{array}$ \\
\cline { 2 - 4 } & Beginning & (Pre) Completion & \\
\hline Yeah, so & I say that would bum you out then, & hunh \\
\hline
\end{tabular}

Figure 1: Topological model for turn and/or turn constructional unit (TCU) organization (Lindström, 2006, p. 83)

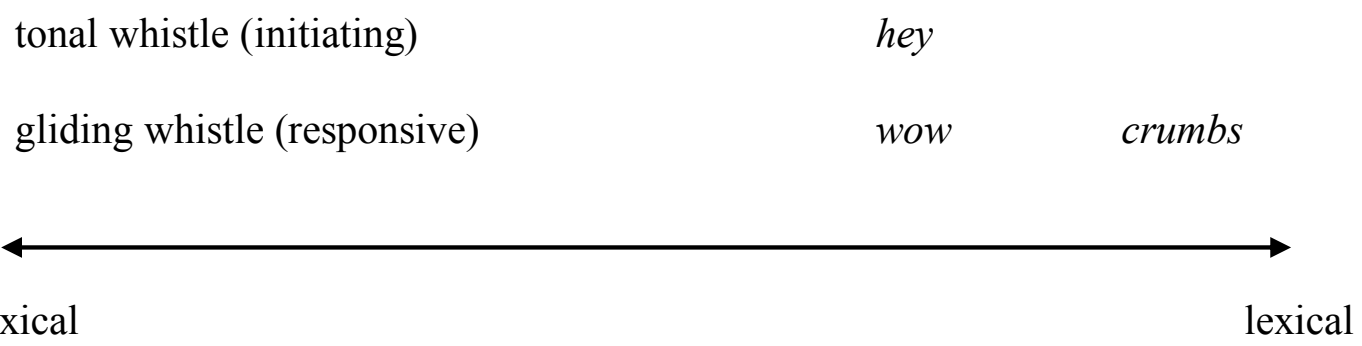

non-lexical

lexical

Figure 12: Non-melodic whistling at the margins of language 


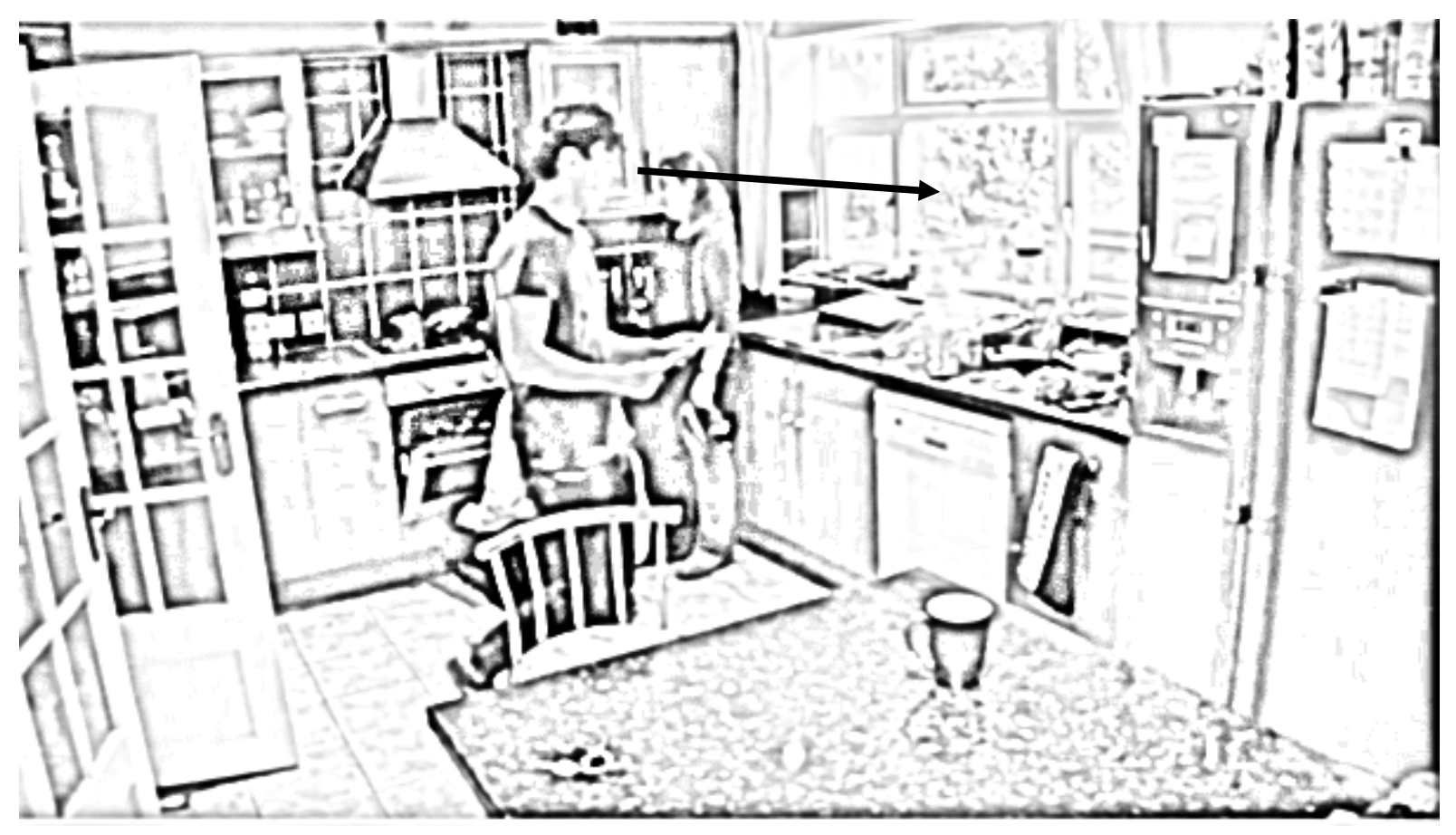

Figure 2: Dan crosses the room, whistling and with visual disengagement (line 6)

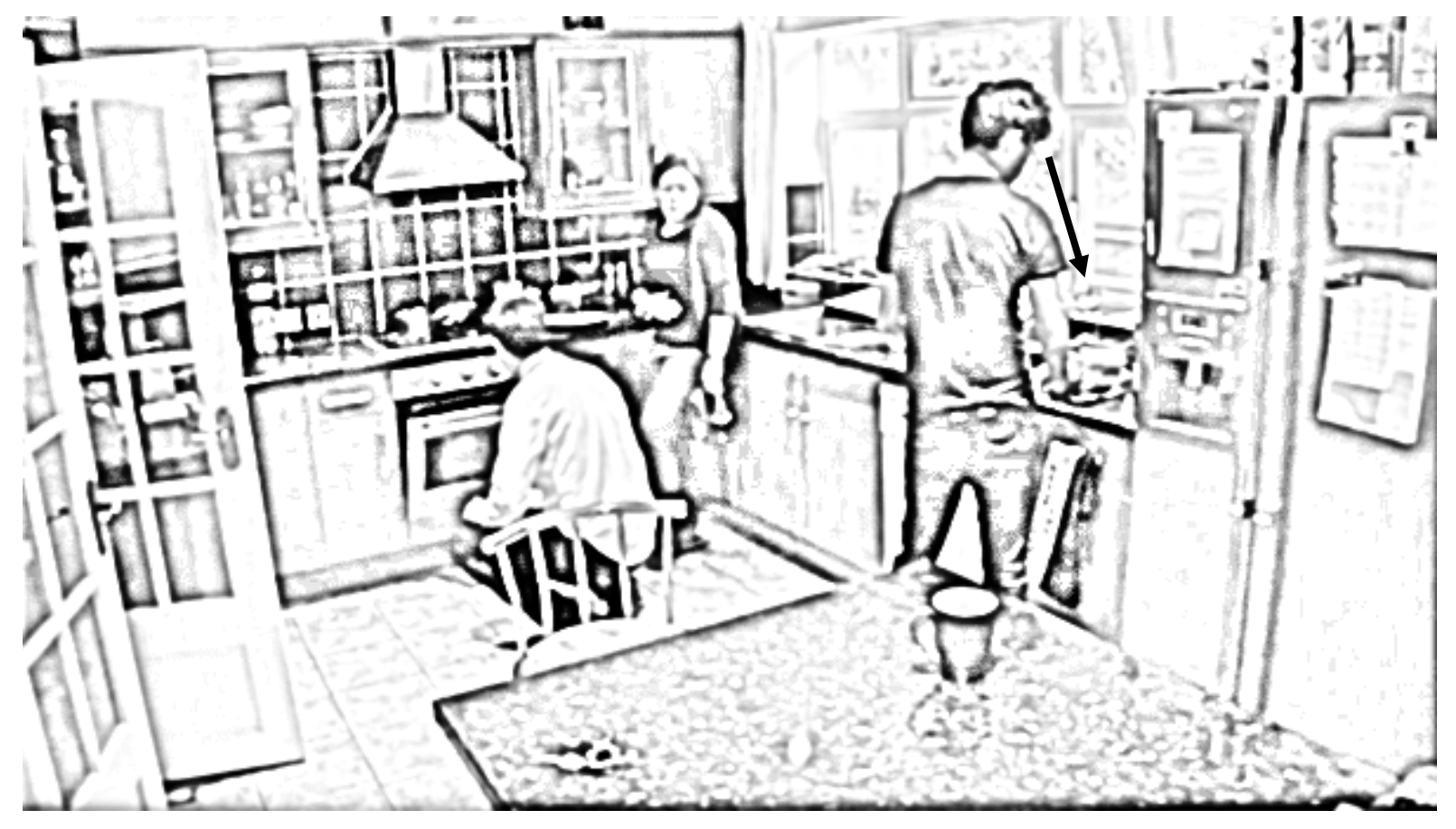

Figure 3: Dan dances at the counter, whistling and displaying visual disengagement (line 10) 


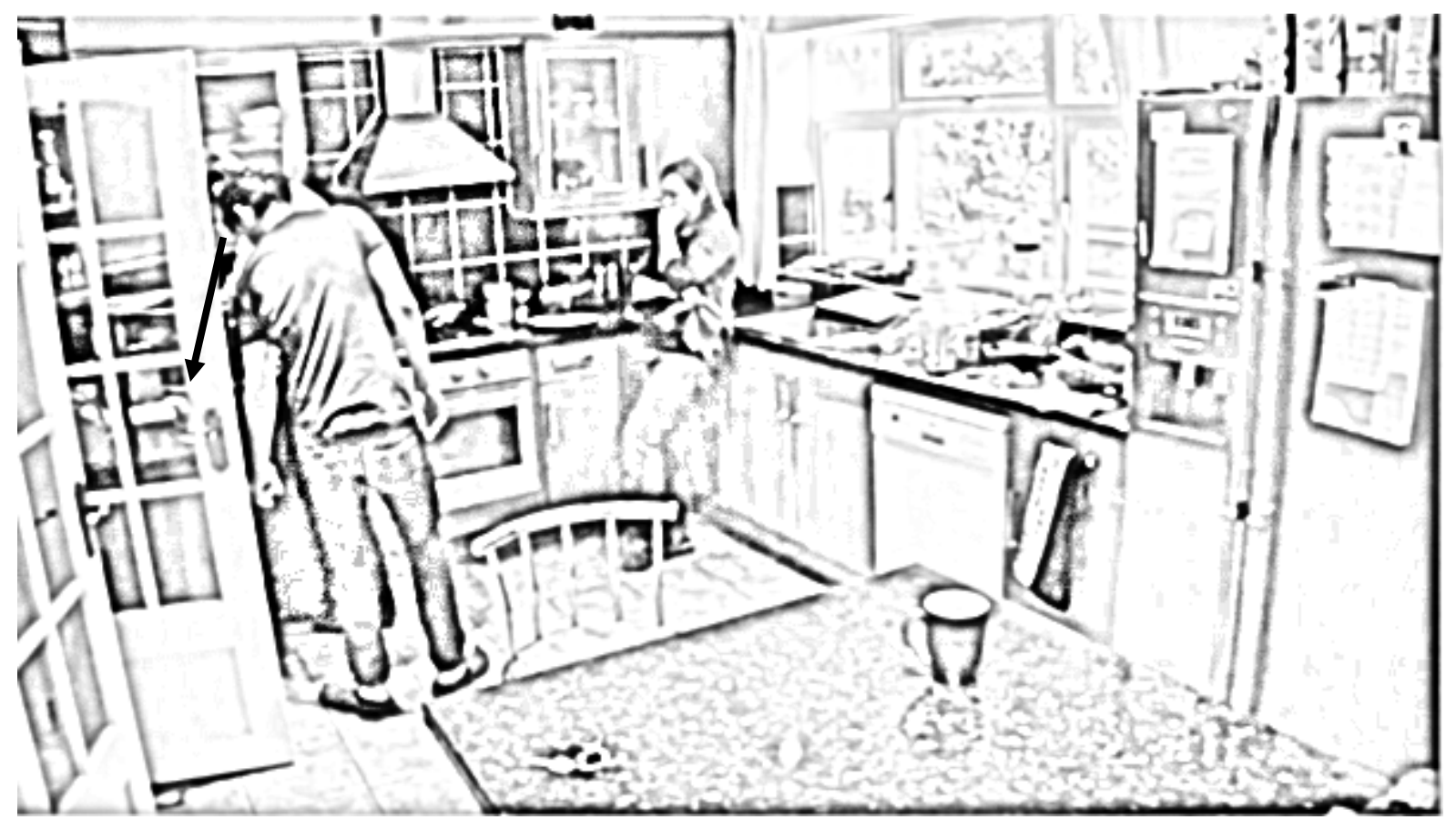

Figure 4: Dan opens drawer, showing visual disengagement (line 15)

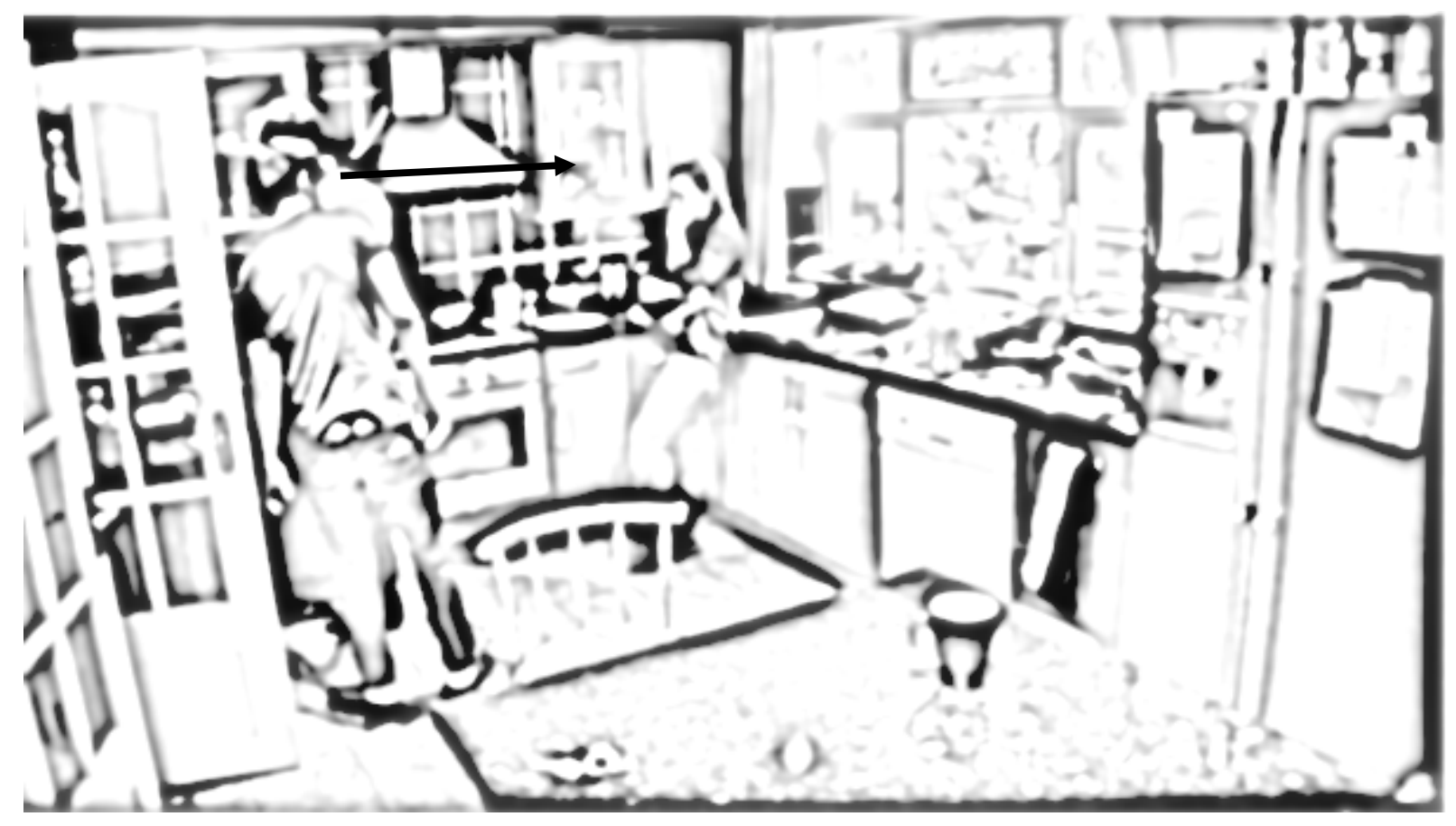

Figure 5: Dan orients his gaze towards Alice (line 16) 


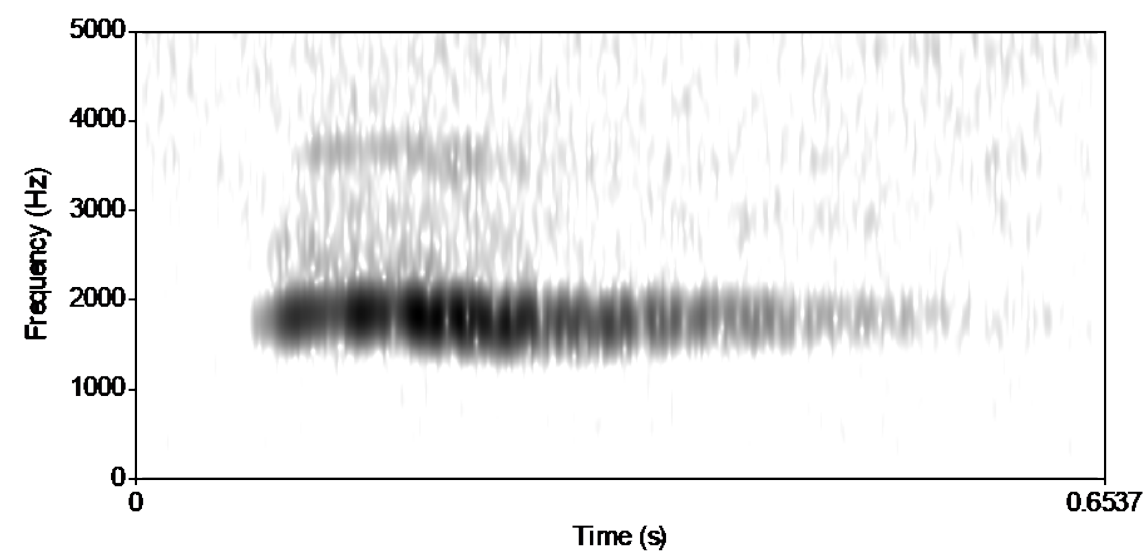

Figure 6: Narrow-band spectrogram of single-tone whistle in Extract (4)

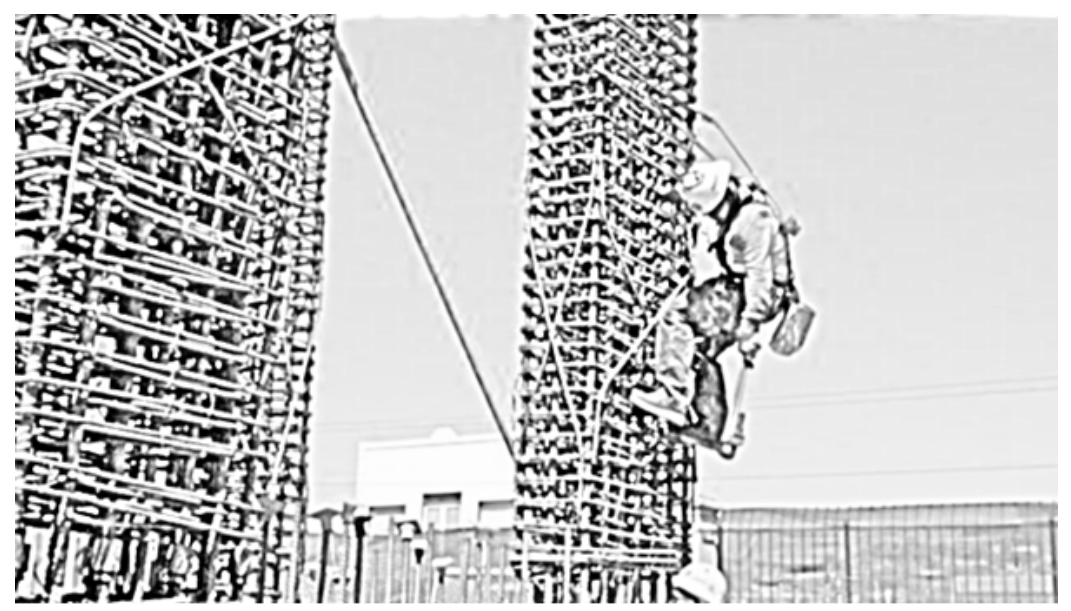

Figure 7a: Horacio produces a single-tone whistle to summon Damian

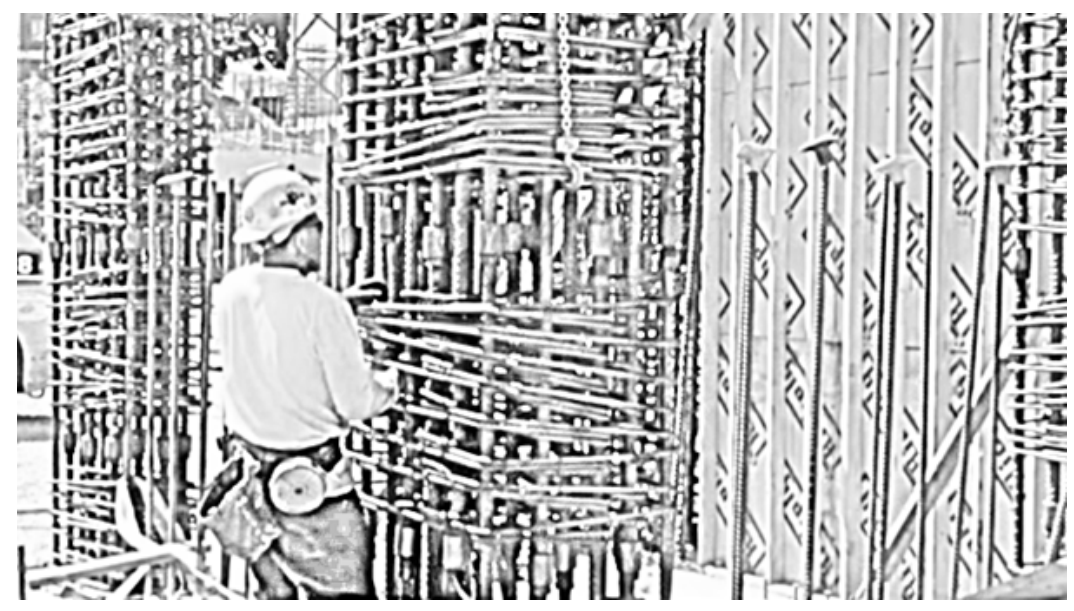

Figure 7b: Damian's bodily orientation during the summons 


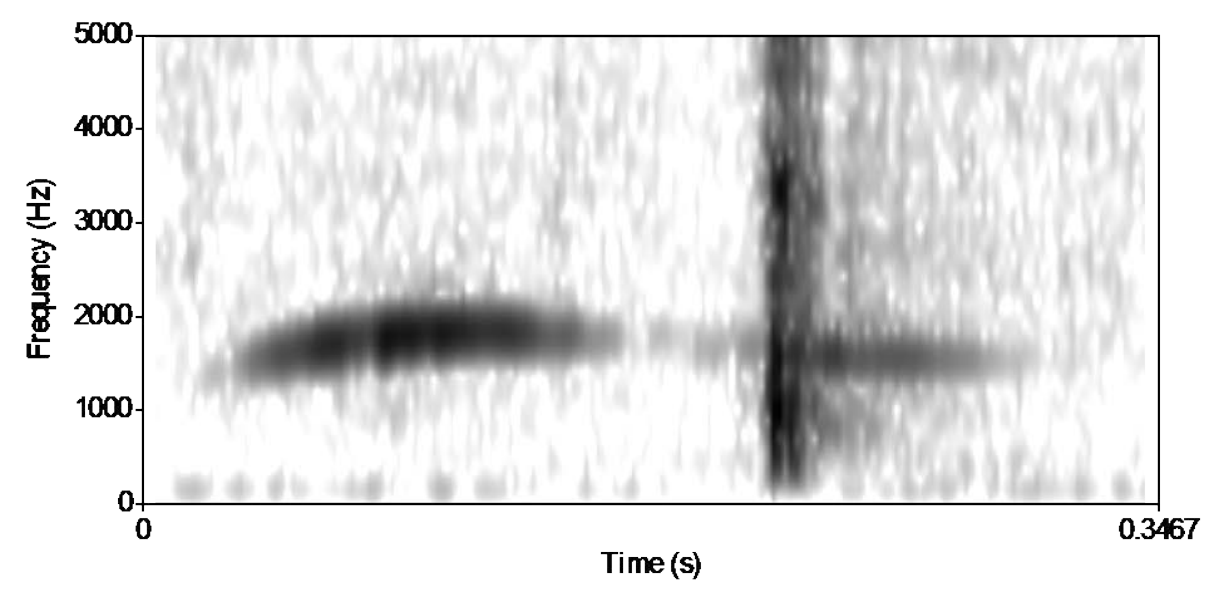

Figure 8: Narrow-band spectrogram of bi-tonal whistle in Extract (6)

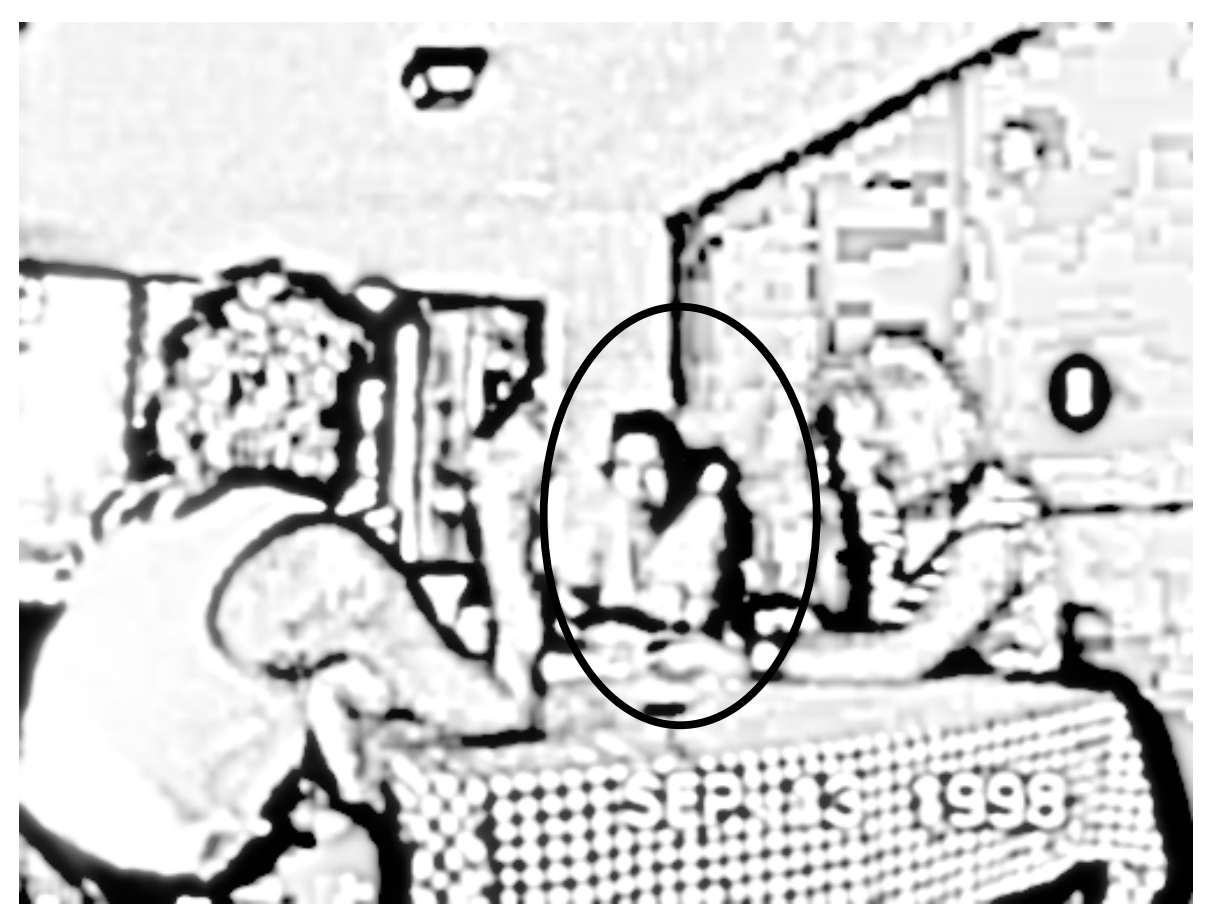

Figure 9: Michelle, who sits at the back on the right, produces a responsive gliding whistle. 


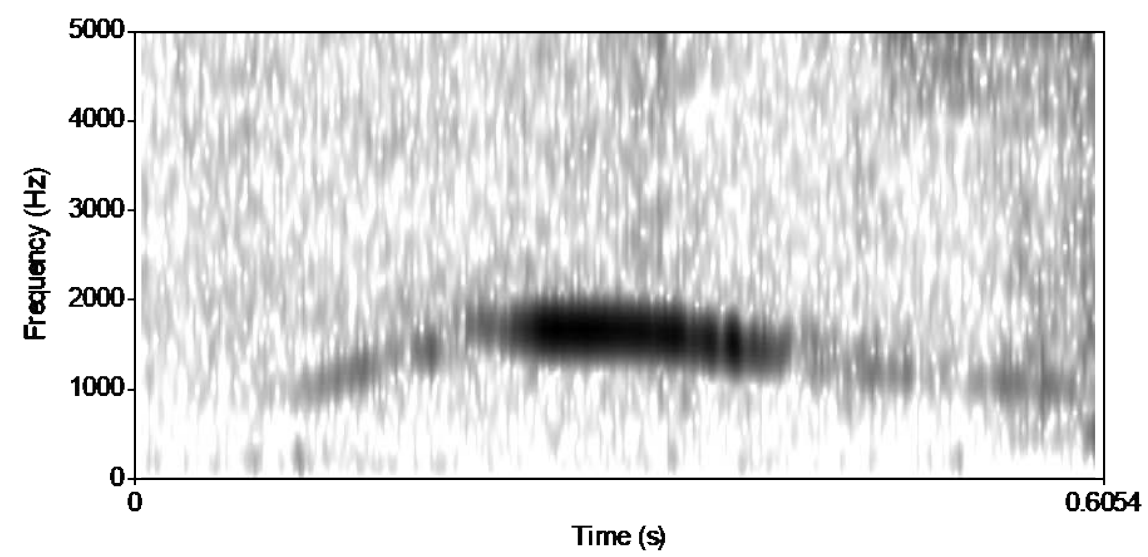

Figure 10: Narrow-band spectrogram of gliding whistle in Extract (8)

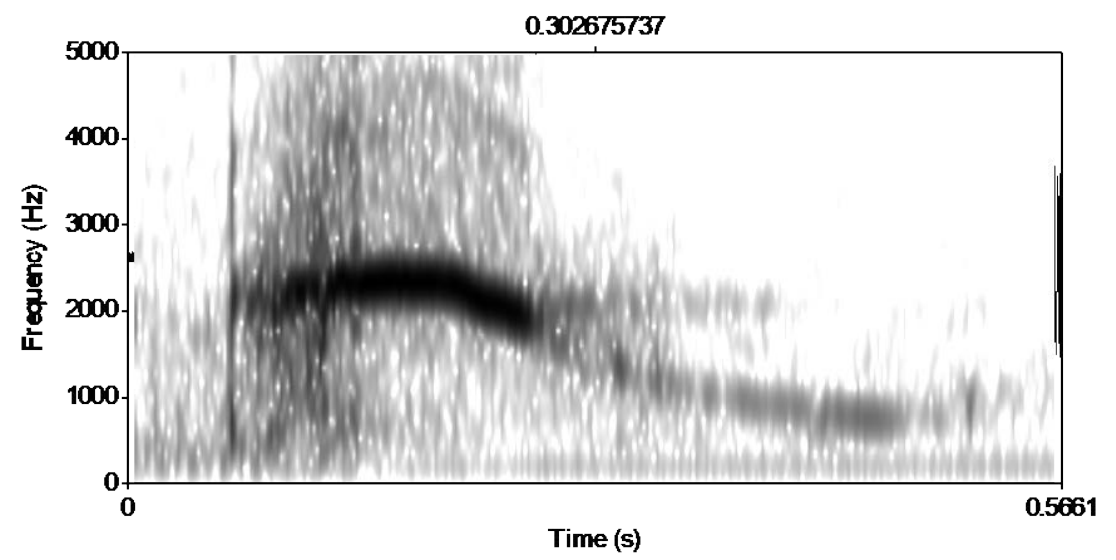

Figure 11: Narrow-band spectrogram of gliding whistle in Extract (9) 